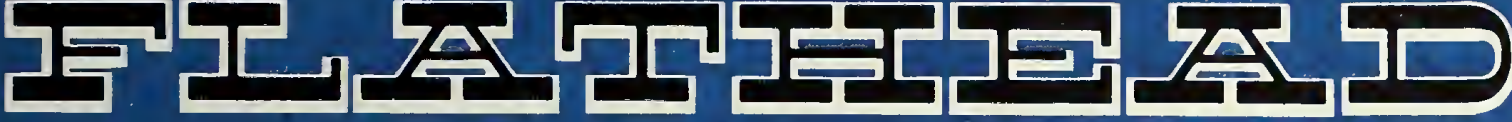

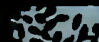
$8 \times-1$

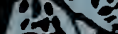

as

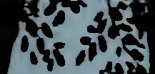

An 134

(4)

d4. 40,5

itophys

topury

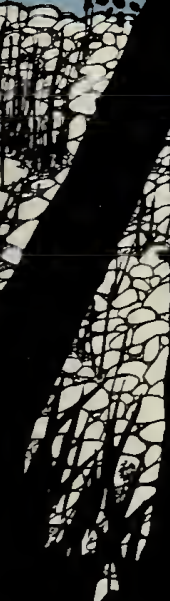

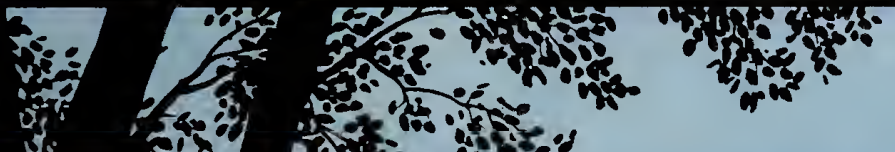

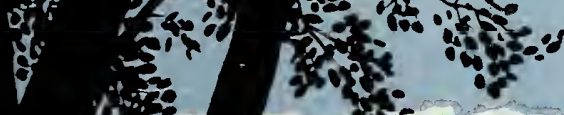

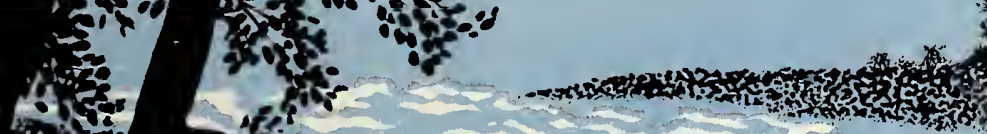

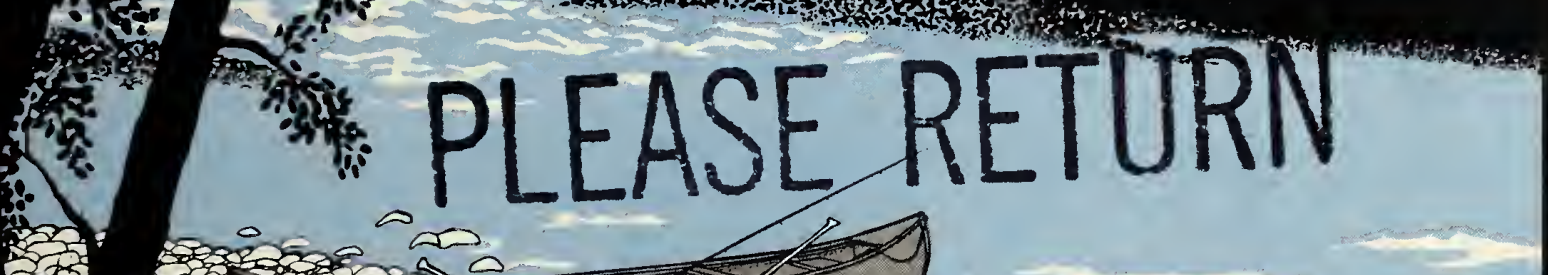

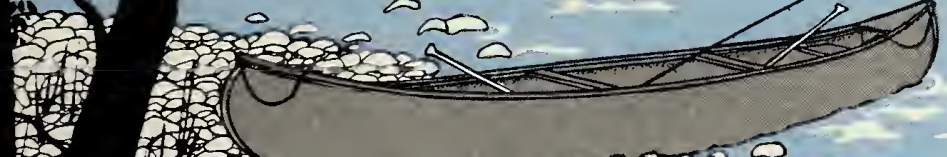

2

GTATE DOCUMENTS COLLECTION

MAY 231984

MONTANA STATE IISRARY

1515 E. CH. AVE.

HELENA, MONIAINA 59620

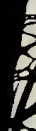
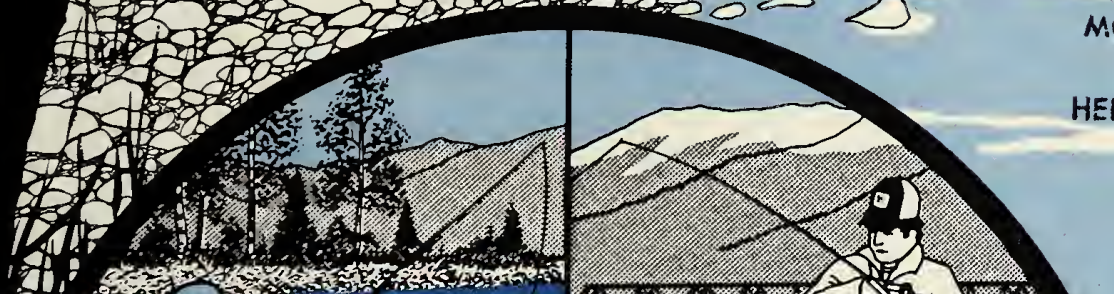

4 .

禺

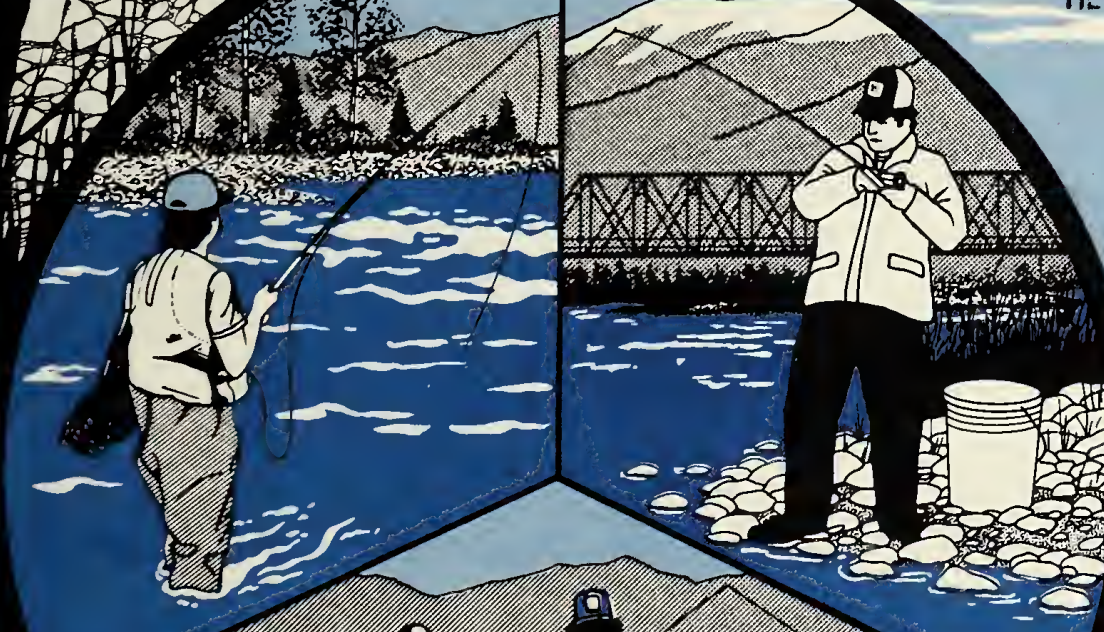

19
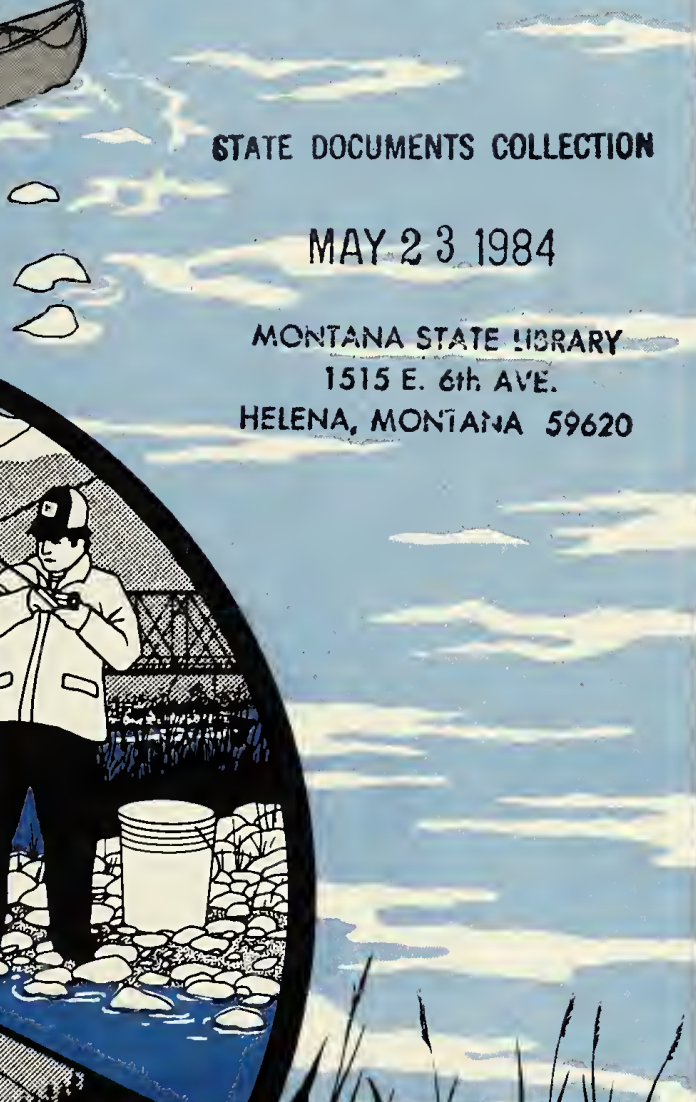

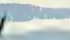

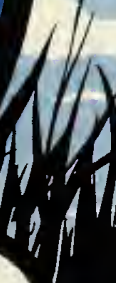

82

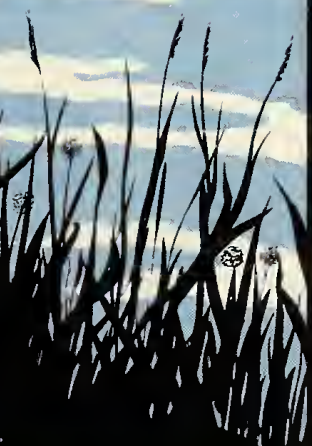

CENSUS OF KOKANEE FISHERMEN ON THE FLATHEAD RIVER

Research Conducted by: MONTANA DEPARTMENT OF FISH, WILDLIFE AND PARKS Sponsored by: BUREAU OF RECLAMATION 
MONTANA STATE LIBRARY

S 799.12 F2ck 1982 c.1 Fredenberg

Census of kokanee fishermen on the Flath

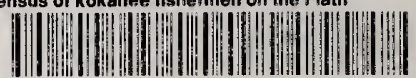

30864000481781

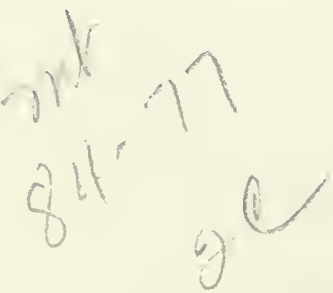




\title{
Census of Kokanee Fishermen \\ on the Flathead River
}

\author{
Prepared by: \\ Wade Fredenberg - Project biologist \\ and \\ -Patrick Graham - Project Leader \\ Montana Department of Fish, Wildlife and Parks \\ Kalispe11, Montana 59901
}

Sponsored by:

Bureau of Reclamation

Boise, Idaho

October 1982 
Digitized by the Internet Archive in 2017 with funding from Montana State Library 
During the 1981 kokanee season on the mainstem Flathead River and the lower Middle Fork (September-November) anglers expended an est ima ted total of 97,000 fisherman hours which equated to over 26,000 angler days. During this period an estimated total of 152,000 kokanee were harvested with approximately equal harvest from the Middle Fork and mainstem Flathead rivers. Over 90 percent of this harvest was by snag fishermen.

Distribution of pressure and harvest between the two rivers varied through the season. On the mainstem Flathead over three-fourths of the pressure and kokanee harvest occurred during the month of September.

By October, the pressure and harvest on the mainstem had moved upstream to Sections MS3 and MS4. The closure of this fishery in all but the upper end of Section MS4, on October 23, effectively ended kokanee harvest for the year on the mainstem Flathead.

Harvest of kokanee in 1981 was nearly identical to that observed in 1975. However, two significant differences were observed between the two years. Virtually the entire kokanee harvest came from the mainstem Flathead River in 1975 and little from the Middle Fork. In 1981, the harvest was divided equally between the two rivers. The timing of harvest also shifted. In 1975, 88 percent of the mainstem harvest occurred during October compared to 24 percent in 1981 . Less than 12 percent of the mainstem harvest occurred during September in 1975, compared to 76 percent in 1981.

These data reflect a shift in fisherman use to the earlier run of salmon destined primarily for McDonald Creek and the lower Middle Fork River areas. The shift is in response to the decline in numbers of spawners returning to the mainstem Flathead River due to excessive incubation mortality suffered from water level fluctuations discharged from Hungry Horse Dam. 

EXECUTIVE SUMMARY .................. i i

LIST OF TABLES. . . . . . . . . . . . . . . . . . v

LIST OF FIGURES . . . . . . . . . . . . . . . . vii

INTRODUCTION. . . . . . . . . . . . . . . . . 1

DESCRIPTION OF STUDY AREA . . . . . . . . . . . . 2

KOKANEE POPULATION AND FISHING REGULATIONS ....... . 5

Kokanee Salmon Life History. . . . . . . . . 5

Fishing Seasons and Limits........... . 9

METHODS ............................ 9

RESULTS .............................. 12

CHARACTERISTICS OF THE KOKANEE FISHERY . . . . . . . . 12

Lure Fishery Mainstem Flathead . . . . . . . . 12

CHARACTERISTICS OF THE KOKANEE FISHERY . . . . . . . . 12

Snag Fishery Mainstem Flathead . . . . . . . 12

CHARACTERISTICS OF THE KOKANEE FISHERY . . . . . . . 17

Snag Fishery Middle Fork . . . . . . . . . 17

FISHING PRESSURE . . . . . . . . . . . . 19

Mainstem Flathead River . . . . . . . . . 19

Middle Fork .................. 2 21

KOKANEE HARVEST ........................ 25

Mainstem Flathead River .......... 25

Middle Fork Flathead River ........... 28

South Fork and Swan River . . . . . . . . . 28

SIZE DISTRIBUTION OF KOKANEE HARVESTED ON THE MAINSTEM AND

MIDDLE FORK. 
TABLE OF CONTENTS CONT.

Page

SUMMARY AND DISCUSSION. ......................... 32

LITERATURE CITED. . . . . . . . . . . . . 35 
Table

1 Discharges (cubic feet per second) and drainage areas of components of the Flathead River system (USGS 1981) . . . . . .

2 Reach descriptions, lengths and abbreviations for river sections included in this study.

3 A list of fish species occurring in Flathead Lake and the Flathead River upstream from Flathead Lake and their relative abundance: C - common, U - uncommon, and R - rare... . . . . . . . .

4 Distribution of kokanee caught per angler per completed trip by month, area, tackle type, origin and shore versus boat on the Flathead River during 1981. Includes only interviews of 568 anglers not using snagging hooks during late August through November.

5 Monthly kokanee catch and catch rates (in parentheses) for 169 angler parties not using snagging hooks who were interviewed on Sections MSI-MS4 of the Flathead River during August-November, 1981.

6 Distribution of snag fisherman interviews and hours by area and month on four sections of the mainstem Flathead River during 1981.

7 Kokanee catch and catch rates (in parentheses) for snag fishermen interviewed on four sections of the mainstem Flathead River during September-October, 1981

8 Numbers of parties interviewed and hours fished by month on the Middle Fork of the Flathead River during September-October, 1981.

9 Distribution of angler origins for snag fishermen interviewed on the Middle Fork of the Flathead River during September October, 1981

10 Total estimated fishing pressure in hours, by month, with $95 \%$ confidence intervals (in parentheses) for Sections MS1-MS4 of the Flathead River during 1981.

11 Total estimated shore fishing pressure in hours, by month, with 95\% confidence intervals (in parentheses) for Sections MS1-MS4 of the Flathead River during 1981 . . . . . . . . . . .

12 Total estimated boat fishing pressure in hours, by month, with 95\% confidence intervals (in parentheses) for Sections MS1-MS4 of the Flathead River during 1981 
13 Total estimated fishermen pressure in hours exerted by kokanee snaggers from shore and in boats on the lower Middle Fork of Flathead River during September-November, 1981. . . . . . .

14 Total estimated monthly kokanee harvest by all anglers on the four sections of the mainstem Flathead River during 1981. 95\% confidence interval in parentheses for grand total. . . . . .

15 Total estimated monthly kokanee harvest by boat anglers only on four sections of the ma instem Flathead River during 1981. 95\% confidence interval in parentheses for grand total. . . . . .

16 Total estimated monthly kokanee harvest by shore anglers only on the four sections of the mainstem Flathead River during 1981. $95 \%$ confidence interval in parentheses for grand total. . . . .

17 Total estimated kokanee harvest on shore and boat snag fishermen on the lower Middle Fork of the Flathead River during SeptemberNovember, 1981. 95\% confidence interval in parentheses for totals. . . . . . . . . . . . . . . . 


\section{L.IST OF FIGURES}

\section{Figure}

1 Map showing the general relationship of streams in the upper Flathead drainage and Flathead Lake. . . . . . . . . . . 4

2 Study area. Map showing the locations of the eight primary river sections .................. . . 6

3 Length frequency distribution of 489 kokanee harvested by fishermen from the Flathead River (Sections MS1-MS4) and lower Middle Fork (Section MF1) during 1981.......... 30 

The Department of Fish, Wildlife and Parks undertook the present investigation as part of a feasibility level study to evaluate the potential impacts of a proposed enlargement of the power plant and construction of a reregulating dam at Hungry Horse Dam on the South Fork of the Flathead River. This study serves as an extension of previous fishery investigations (McMuli in and Graham 1981; Fraley and Graham 1982) and was designed to quantify the use of the river system associated with the kokanee fishery. Censuses were also conducted on the mainstem Flathead River and North Fork during the summer of 1981 (Fredenberg and Graham 1982) and on Flathead Lake during a one-year period from May, 1981 to May, 1982 (Graham and Fredenberg 1982). An evaluation of the economics of water-based recreation in the Flathead River and Lake system was also completed in conjunction with this Department (Sutherland 1982). This data will be useful in evaluating recreational costs and benefits associated with potential impacts from the proposed hydroelectric project.

The current study focused on the kokanee fishery because impacts associated with discharge fluctuations from Hungry Horse Dam were most significant on kokanee. The kokanee fishery is unique because of the large effort and harvest which occurs in a relatively short time during their spawning run and the method of angling involved. The dominance of this fishery during the fall lends itself to being selectively monitored through creel census and will be reported here separate from the more conventional type of river fishery that exists for other species.

Kokanee were first introduced into the Flathead system in 1916 and have provided a major portion of the lake and river fishery since the early 1930's. Early reports noted heavy runs of kokanee were ascending the Flathead and Swan rivers. Sportsmen took an estimated harvest of 100 tons of kokanee from Flathead Lake in 1933 (Graham 1982).

The only prior census of fishermen on the Flathead River was conducted in 1975 when an estimated total of 150,000 kokanee made up about 88 percent of the gamefish harvested from the mainstem Flathead River (Hanzel 1977). However, since 1978 the kokanee runs have declined in numbers of spawners. This decline appears to be associated with the operation of Hungry Horse Dam (McMullin and Graham 1981; Fraley and Graham 1982). The changes in the fishery associated with the decline in kokanee runs were documented in this report. 
The Flathead River originates at the confluence of its North and Middle Forks along the western edge of Glacier National Park in northwest Montana (Figure 1). From there it flows south for $15 \mathrm{~km}$ before being joined by the South Fork near the town of Hungry Horse. The Flathead River enters the north end of Flathead Lake some $89 \mathrm{~km}$ downstream from the junction of the North and Middle Forks. The gradient of the mainstem Flathead River averaged $1.6 \mathrm{~m} / \mathrm{km}$ above Columbia Falls and $0.4 \mathrm{~m} / \mathrm{km}$ in the valley portion downstream from Columbia Falls.

The Middle Fork of the Flathead River originates at the northern end of the Bob Marshall Wilderness (Figure 1). It flows generally northwesterly through the Great Bear Wilderness and then on to its confluence with the North Fork. From Bear Creek downstream it forms the southern boundary of Glacier National Park. Numerous tributaries drain into the river including McDonald Creek, which drains 6,800 acre Lake McDonald in Glacier National Park.

The gradient of the Middle Fork averages $4.9 \mathrm{~m} / \mathrm{km}$. Our two study sections from the mouth to Harrison Creek and from Harrison Creek to 01 e Creek have average gradients of $2.5 \mathrm{~m} / \mathrm{km}$ and $3.2 \mathrm{~m} / \mathrm{km}$, respectively.

The South Fork of the Flathead River originates at the southeast end of the Bob Marshall Wilderness and flows $92 \mathrm{~km}$ before entering Hungry Horse Reservoir (Figure 1). The reservoir is $65 \mathrm{~km}$ long and is impounded by 564 foot high Hungry Horse Dam which was closed in 1952. No fish passage facility exists. The South Fork above the reservoir has an average gradient of $3.9 \mathrm{~m} / \mathrm{km}$. The $8 \mathrm{~km}$ reach of the South Fork below Hungry Horse Dam is altered by the dam and subject to fluctuations in discharge and water temperature. Fluctuations on the South Fork also can cause considerable flow variation in the mainstem Flathead River below the junction of the South Fork during the normal low flow period.

The Swan River drains the Swan and Mission mountain ranges and flows north for $11 \mathrm{~km}$ to enter the northeast corner of Flathead Lake after flowing through 2,680 acre Swan Lake, which 1 ies adjacent to Flathead Lake on the east. A twelve foot high diversion dam at Bigfork, constructed in 1902, acts as a barrier for fish going upstream from Flathead Lake to the Swan drainage. Only $2 \mathrm{~km}$ of the Swan River 1 ies below this dam.

A considerable amount of information on water temperatures, flows, geology, water quality, and land use in the Flathead River and its tributaries was summarized in earlier reports by the Department of Fish, Wild1 ife and Parks (Graham et a1. 1980; Fraley et a1. 1981; McMullin and Graham 1981; Perry and Graham 1981).

The three forks of the Flathead River are approximately equal in size with mean annual flows of $3,000-3,500 \mathrm{cfs}$ (Table 1). The maximum flow of the Middle Fork during the 1964 flood was the highest on record and more than double that recorded on the other two forks (Table 1). 


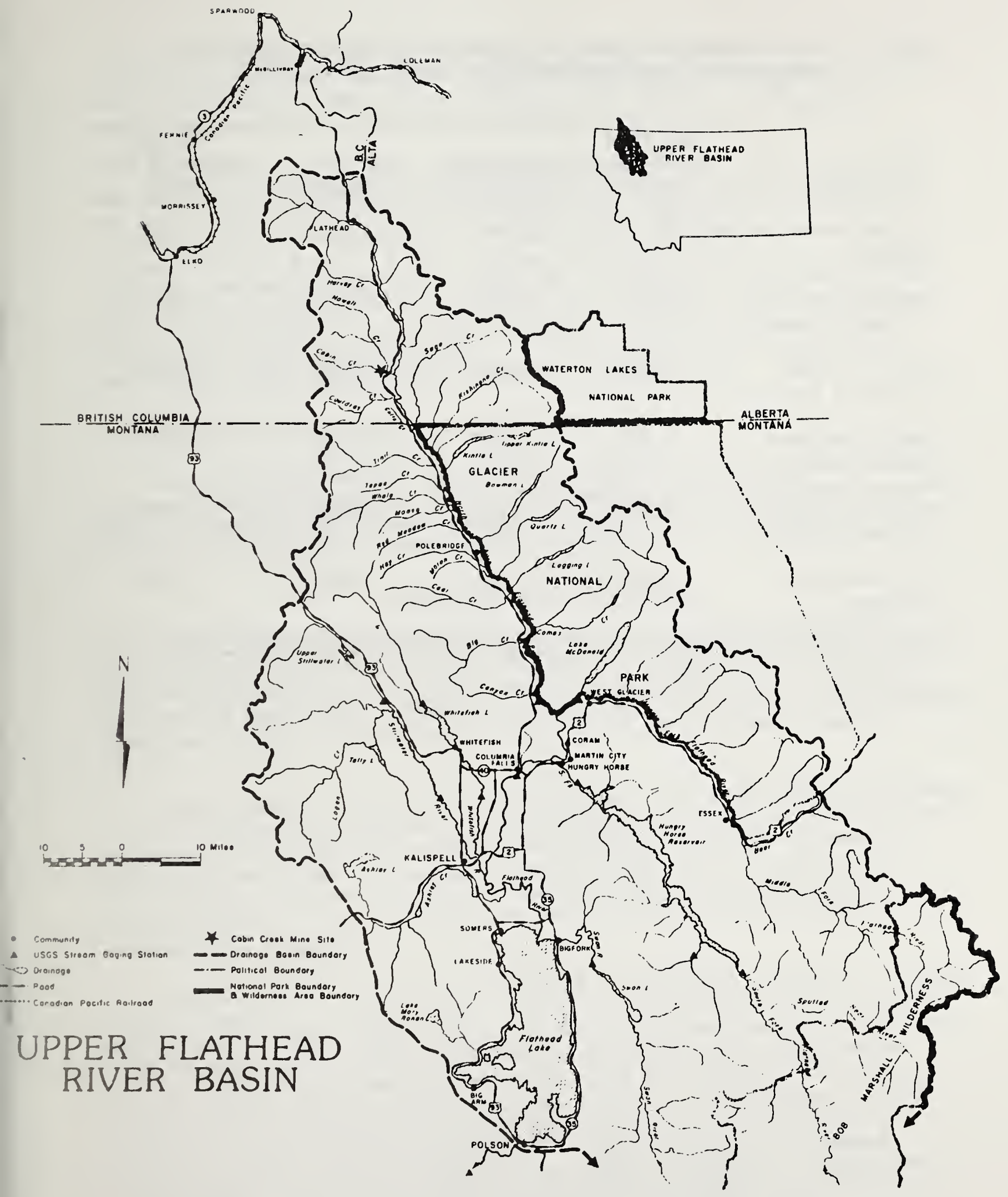

Figure 1. Map showing the general relationship of streams in the upper Flathead drainage and Flathead Lake. 
Table 1. Discharges (cubic feet per second) and drainage areas of components of the Flathead River system (USGS 1981).

\begin{tabular}{lcccc}
\hline Drainage & $\begin{array}{c}\text { Drainage } \\
\text { area } \\
\left(\mathrm{km}^{2}\right)\end{array}$ & $\begin{array}{c}\text { Mean annual } \\
\text { flow(cfs) }\end{array}$ & $\begin{array}{c}\text { Maximum } \\
\text { flow(cfs) }\end{array}$ & $\begin{array}{c}\text { Minimum } \\
\text { recorded flow } \\
\text { (cfs) }\end{array}$ \\
\hline $\begin{array}{l}\text { Flathead River near } \\
\text { Polson }\end{array}$ & 18,379 & 11,740 & 82,800 & $<5$ \\
$\begin{array}{l}\text { Flathead River at } \\
\text { Columbia Falls }\end{array}$ & 11,562 & 9,753 & 176,000 & 798 \\
$\begin{array}{l}\text { North Fork near } \\
\text { Columbia Falls }\end{array}$ & 4,009 & 2,990 & 69,100 & 198 \\
$\begin{array}{l}\text { Middle Fork near } \\
\text { West Glacier }\end{array}$ & 2,922 & 2,948 & 140,000 & $<173$ \\
$\begin{array}{l}\text { South Fork near } \\
\text { Columbia Falls }\end{array}$ & 4,307 & 3,571 & 46,200 & 7 \\
$\begin{array}{l}\text { Swan River near } \\
\text { Bigfork }\end{array}$ & 1,738 & 1,166 & 8,890 & 193 \\
\hline
\end{tabular}


The minimum flow of $7 \mathrm{cfs}$ on the South Fork occurred during construction of Hungry Horse Dam. The normal operating regime on the South Fork allows daily fluctuations from a low of $150 \mathrm{cfs}$ to as high as $11,400 \mathrm{cfs}$ in only a few hours with vertical fluctuations as great as 2.5 meters.

For the purpose of the census, the Flathead River system was divided into seven river segments, four on the mainstem, two on the Middle Fork, and one on the South Fork (Table 2, Figure 2). Additional reference is made to the lower Swan River. Flathead River system sections vary in length from 8.4 to $41.5 \mathrm{~km}$. The four sections of the mainstem Flathead River were abbreviated with the prefix MS and numbered in upstream order starting from the mouth (Table 2, Figure 2). The same numbering system was used on the Middle Fork, abbreviated MF, South Fork, abbreviated SF, and Swan River, abbreviated SR. For the remainder of this report these abbreviated descriptions were used; MS1, MS2, etc.

\section{KOKANEE POPULATION AND FISHING REGULATIONS}

There were at least 22 fish species present in the Flathead River upstream from Flathead Lake (Table 3 ). The bull trout, westslope cutthroat trout and kokanee were the most important game species found in the river. A brief life history is presented for kokanee.

\section{Kokanee Salmon Life History}

Large numbers of migrating kokanee normally first appeared in the lower Flathead River during early September. Timing of the initial appearance was fairly constant, but the subsequent migration rate of kokanee varied from year to year (McMullin and Graham 1981). The mainstem Flathead River was used as a migration corridor as well as a kokanee spawning area.

Most spawning of kokanee occurred between mid-October and mid-December in the Flathead River system. Following spawning, the adults died. Eggs deposited in the gravel developed over the winter and the fry emerged and moved downstream to Flathead Lake during the spring, primarily in April and May. After three to five growing seasons in the lake (four for the majority), the adult fish returned to the spawning grounds to complete the life cycle.

Kokanee spawning occurred throughout the mainstem Flathead in suitable areas, primarily in side channels and spring-influenced sloughs. Heavy mortality of spawned eggs occurred in the river downstream from the South Fork as well as the South Fork below the dam due to dewatering caused by fluctuating water levels from Hungry Horse Dam (McMullin and Graham 1981; Fraley and Graham 1982). A major portion of the kokanee run progressed up the Middle Fork with the majority of these fish spawning in McDonald Creek in Glacier National Park. Some kokanee also spawned in the main Middle Fork and some of its other tributaries. Kokanee were seldom found above Nyack Flats on the Middle Fork which is just above Section MF1. Kokanee were rarely observed in the North Fork. 


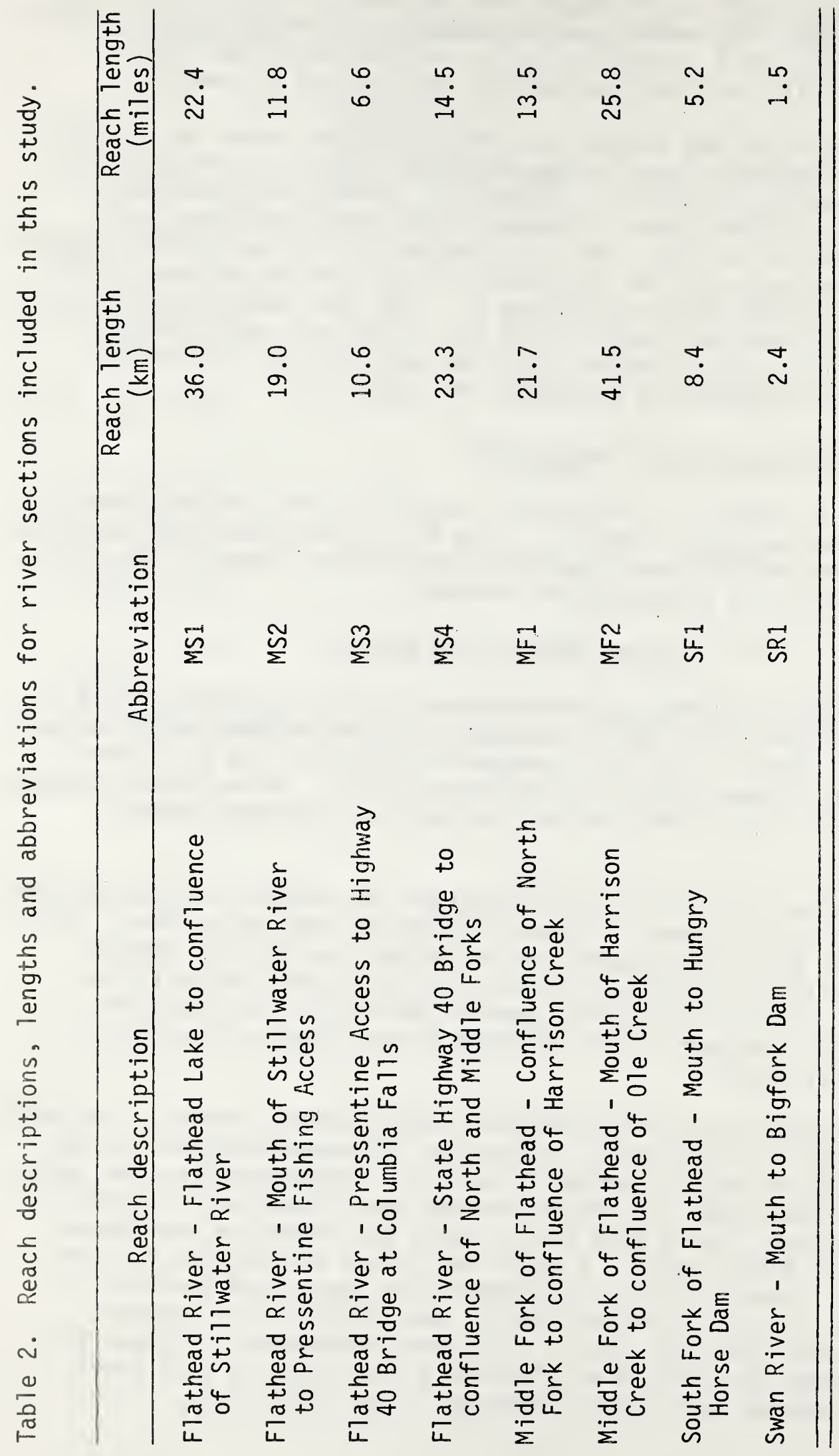




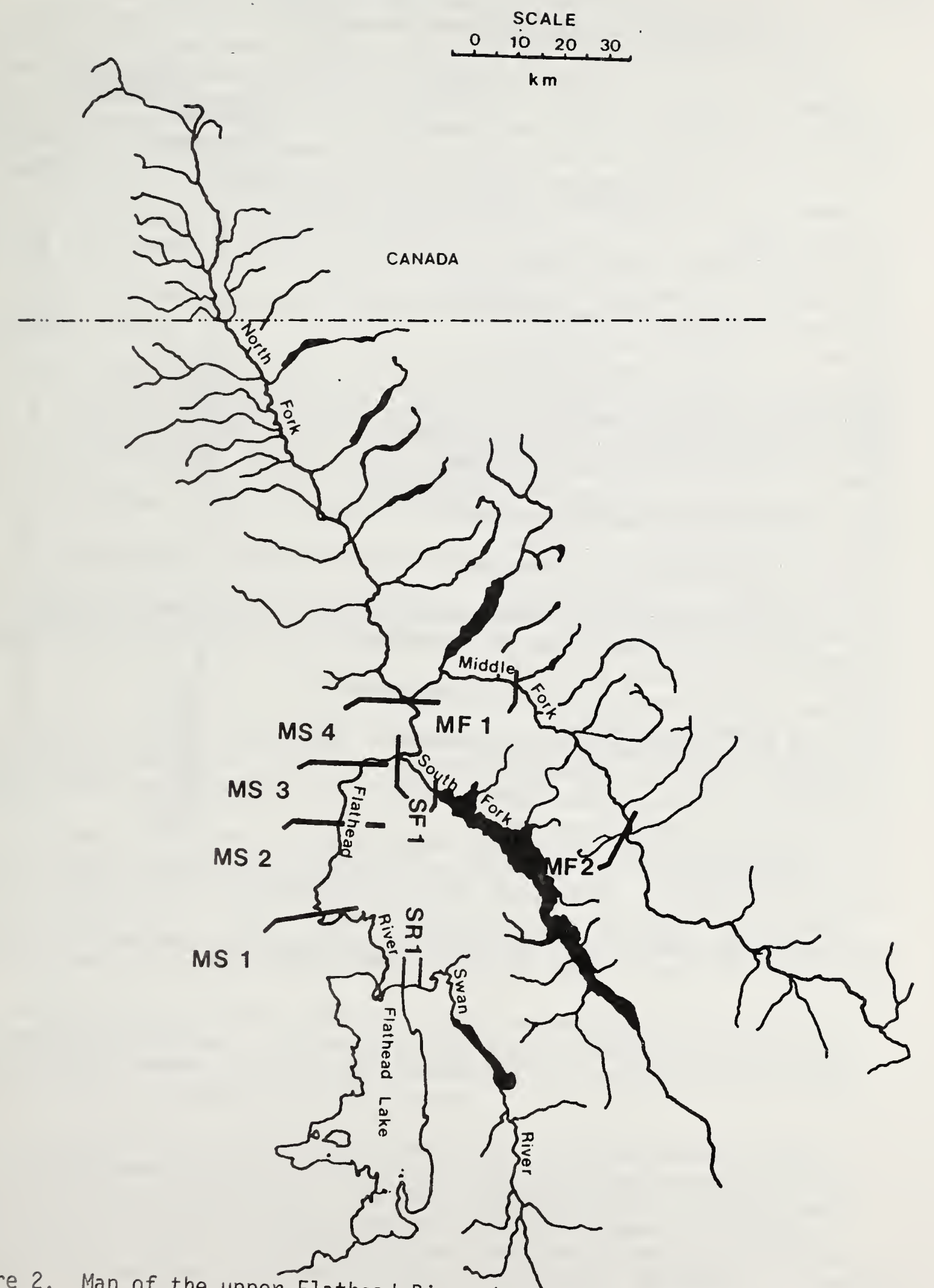

Figure 2. Map of the upper Flathead River drainage showing the eight
river sections used during the 
Table 3. A list of fish species occurring in Flathead Lake and the Flathead River upstream from Flathead Lake and their relative abundance: C - common, U - uncommon, and R - rare.

\begin{tabular}{|c|c|c|}
\hline \multirow[b]{2}{*}{ Fish Species } & \multicolumn{2}{|c|}{ Abundance } \\
\hline & $\begin{array}{l}\text { Mainstem } \\
\text { Flathead } \\
\text { River }\end{array}$ & $\begin{array}{c}\text { Flathead } \\
\text { Lake } \\
\end{array}$ \\
\hline $\begin{array}{l}\text { Cutthroat trout } \\
\text { Westslope (Salmo clarki lewisi) } \\
\text { Yellowstone (Salmo clarki bouvieri) } \\
\text { Bul1 trout (Salvelinus confluentus) } \\
\text { Rainbow trout (Salmo gairdneri) } \\
\text { Brook trout (Salvelinus fontinalis) } \\
\text { Lake trout (Salvelinus namaycush) } \\
\text { Kokanee (Oncorhynchus nerka) } \\
\text { Lake whitefish (Coregonus clupeaformis) } \\
\text { Pygmy whitefish (Prosopium coulteri) } \\
\text { Mountain whitefish (Prosopium williamsoni) } \\
\text { Arctic grayling (Thymallus arcticus) } \\
\text { Slimy sculpin (Cottus cognatus) } \\
\text { Shorthead sculpin (Cottus confusus) } \\
\text { Mottled sculpin (Cottus bairdi) } \\
\text { Longnose sucker (Catostomus catostomus) } \\
\text { Largescale sucker (Catostomus macrocheilus) } \\
\text { Peamouth (Mylocheilus caurinus) } \\
\text { Northern squawfish (Ptychocheilus oregonensis) } \\
\text { Northern pike (Esox lucius) } \\
\text { Redside shiner (Richardsonius balteatus) } \\
\text { Largemouth bass (Micropterus salmoides) } \\
\text { Pumpkinseed (Lepomis gibbosus) } \\
\text { Yellow perch (Perca blavescens) } \\
\text { Black bulihead (Ictalurus melas) }\end{array}$ & $\begin{array}{l}C \\
C \\
\mathrm{R} \\
C \\
U \\
\mathrm{R} \\
\mathrm{R} \frac{1}{1 /} \\
\mathrm{C} \frac{1}{1} / \\
\mathrm{U}=1 / \\
\mathrm{C} \\
\mathrm{R} \\
\mathrm{C} \\
\mathrm{C} \\
? \\
\mathrm{U} \\
\mathrm{C} \\
\mathrm{C} \\
\mathrm{C} \\
\mathrm{R} \frac{2}{2} / \\
\mathrm{R} \frac{1}{2 /} \\
\mathrm{R} \frac{1}{2 /} \\
\mathrm{R} \frac{2}{2} / \\
\mathrm{R}=\end{array}$ & $\begin{array}{l}\mathrm{C} \\
\mathrm{C} \\
\mathrm{R} \\
\mathrm{C} \\
\mathrm{R} \\
\mathrm{R} \\
\mathrm{C} \\
\mathrm{C} \\
\mathrm{C} \\
\mathrm{C} \\
\mathrm{C} \\
- \\
\mathrm{C} \\
? \\
? \\
\mathrm{C} \\
\mathrm{C} \\
\mathrm{C} \\
\mathrm{C} \\
\mathrm{R} \\
\mathrm{C} \\
\mathrm{U} \\
\mathrm{R} \\
\mathrm{C} \\
\mathrm{R}\end{array}$ \\
\hline
\end{tabular}

1/ Refers to seasonal abundance.

2) Common in some sloughs along the lower river. 
The open stream fishing season in the Flathead River system runs from the third Saturday in May through the end of November. In 1981, this included 199 days from May 16 through November 30. The snagging season for kokanee was open from September 1 through December 31 except for the segment of the mainstem Flathead downstream from the South Fork which was closed by emergency order of the Fish and Game Commission after October 23, 1981. There was also an extended whitefish fishing season on all portions of the Flathead River system. Whitefish were the only species that could be kept from December 1 through March of 1982, but during this season the river received very little fishing pressure.

Each fisherman on the Flathead River system could take all of the following limits:

1. Trout and grayling - ten pounds and one fish or ten fish, whichever is reached first. Two fish may always be taken, regardless of weight and bull trout must be at least 18 inches total length to be kept. Only one daily limit allowed in possession.

2. Kokanee - thirty-five fish daily and seventy in possession.

3. Whitefish - thirty fish daily and sixty in possession.

Various other limits apply to some of the gamefish species less frequently encountered on the Flathead River and its forks.

\section{METHODS}

A partial creel census was conducted on sections MS1-MS4 of the mainstem Flathead River from May 16 through November 30, 1981, thus providing complete coverage of the 199-day season.

On the Middle Fork of the Flathead River (sections MF1 and MF2), partial creel census was conducted from September 12 to November 30, 1981 , a total of 80 days including eleven full weeks plus the final three days of the season. The purpose of this fall census was to gather data on the kokanee snag fishery which provided the bulk of the annual fishing pressure on the lower Middle Fork.

Weekdays were treated separately from weekend days in setting up the sampling schedule. Four weekdays and three weekend days were chosen completely at random during each two-week period, resulting in half of the days being censused during the season.

Starting times were chosen at random with non-replacement within two-week intervals to assure that counts and interviews were conducted during all the daylight hours. As the season progressed, starting and ending times were adjusted to compensate for fewer hours of daylight. The holiday of Monday, September 7 (Labor Day) was a sample day and was treated as a weekend day. The holidays of Wednesday, November 11 (Veteran's 
Day) and Thursday, November 26 (Thanksgiving) were not scheduled sample days.

The basic creel census design was a modification of the method described by Neuhold and Lu (1957). In river sections MS1 through MS4 (the mainstem Flathead River) aerial counts from a fixed-wing aircraft were made twice a day on all scheduled sample days, weather permitting, from May 16 through November 30. The time of one of the two flights each day was randomly chosen, from 7:30 a.m. to 7:30 p.m., with the other flight of the day beginning six hours before or after the start of the first flight, depending on the hours of available daylight. All flights originated from Kalispel1 and counts were conducted in upstream order. During the peak salmon fishing period of September 13 to October 30, flights were conducted three times a day at three hour intervals from a randomly selected starting hour.

With the onset of the fall kokanee spawning runs, there was a pronounced increase in fishing pressure associated with the Middle Fork of the Flathead River (Sections MF1 and MF2). In response to this, aerial flights were initiated on the Middle Fork. Counts were made three times daily at three-hour intervals on Section MF1 from September 14 through November 30 and on Section MF2 from October 9 through November 30.

A11 counts required less than fifteen minutes per section and thus were considered as instantaneous in analys is of data. A normal flight from Flathead Lake to Section MF2 in the Middle Fork was 45 minutes. Heavy concentrations of fishermen or poor weather conditions increased flight time to a maximum of $1 \frac{1}{2}$ hours. Only those individuals seen actually fishing or with rods nearby were counted as fishermen. Anglers associated with boats were considered to be boat fishermen if they were fishing from the shore when counted.

Creel clerks worked eight 10-hour days during each two-week period. At least one creel clerk was on the ground during most scheduled count days. When fishermen use increased, as many as three creel clerks conducted interviews.

Creel clerks interviewed fishermen on a party basis with emphasis on the collection of complete trip interviews. Party representatives were asked questions about the number of anglers, where they were from, whether they fished from shore or used a boat, what type of terminal tackle they used, how many hours they had fished, and whether or not they were done fishing for that particular day. In addition, information on the number and species of gamefish kept as well as those released was gathered. Random data on lengths of fish harvested was taken by the clerks as time allowed. People interviewed were also asked several questions about any other forms of water-based recreation they had engaged inon the Flathead (swimming, boating, etc.). Additional questions were asked to ascertain the economic value of water-based recreation on the Flathead River and Lake (Sutherland 1982). 
Angler counts and data obtained from interviews was recorded directly on coding forms and keypunched for computer analysis. Analysis was done by the Department of Fish, Wildlife and Parks following the procedures of Neuhold and Lu (1957), using a computer program developed by the Department. Estimates were formulated on a monthly basis with weekdays and weekends lumped together after determining there were no significant differences between them. Pressure estimates were based on the average number of daylight hours available during the month under consideration (one-half hour before sunrise to one-half hour after sunset).

Monthly, seasonal, and overall catch rates were calculated as simply the number of fish caught divided by the total number of hours fished for the sample of anglers interviewed. Harvest rate was the catch rate for only those fish kept by anglers. The harvest was estimated by multiplying pressure by harvest rate for each stratum (month) and then adding the months together. 
This report deals specifically with the kokanee fishery, primarily on the mainstem Flathead River (Sections MS1-MS4) and lower Middle Fork (Section MF1). For the most part, this was a snag fishery, but early in the season fishermen were successful with lures in the lower river. Kokanee fishermen using lures could not be distinguished from non-kokanee fishermen in this census, although they dominated the early September fishery. Pressure was calculated by month and could not be separated by kokanee versus non-kokanee fishermen.

\section{CHARACTERISTICS OF THE KOKANEE FISHERY}

\section{Lure Fishery Ma instem Flathead}

Kokanee first moved into the lower mainstem Flathead River on their spawning run during August, 1981. Most of the kokanee caught by nonsnag fishermen were caught during September in Section MSI using lures and baited lures and fishing from boats (Table 4). This traditional fishery exploited the first concentrations of salmon running upstream from Flathead Lake. As the fish matured they stopped taking lures and snagging became the only method by which kokanee were normally caught. The early fall lure fishery occurred primarily in slow, deep holes of the lower river (Section MS1). All of the kokanee caught by nonsnag fishermen were kept. Overall, nonsnag fishermen interviewed in the ma instem Flathead River during the entire season (May 16 - November 30) kept more kokanee per completed trip (0.69) than any other species, even though kokanee were only available for a limited period of time during the fall.

About 27 percent of the catch by conventional anglers (non-snaggers) interviewed for the entire season consisted of kokanee. Kokanee catch rates (Table 5) were highest in Section MS1. Over 77 percent of the total kokanee caught by nonsnag fishermen that were interviewed were caught in September. Overal1, nonsnag anglers caught an average of 0.5 kokanee per hour during the period kokanee were in the river (1ate AugustNovember.

\section{CHARACTERISTICS OF THE KOKANEE FISHERY}

\section{Snag Fishery Ma instem Flathead}

The snagging season for kokanee began on 1 September, 1981. As the salmon moved upstream out of the lower river into the shallower depths and faster currents of the more upstream sections, snagging by shore fishermen became the primary method of kokanee harvest. Access for shore fishermen was also better in upstream sections. The snagging season was allowed by the Department for the purpose of cropping excess spawners and was highly selective for schooling kokanee. 


\begin{tabular}{|c|c|c|c|c|c|}
\hline \multicolumn{2}{|r|}{ 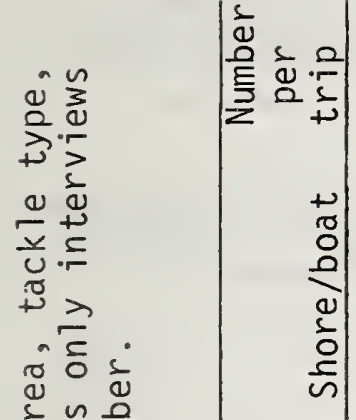 } & $\begin{array}{l}\overrightarrow{0} \\
\dot{0} \\
0 \\
0 \\
\frac{0}{n}\end{array}$ & $\begin{array}{l}\stackrel{2}{m} \\
\stackrel{-}{-} \\
\stackrel{0}{\circ} \\
\stackrel{0}{\circ}\end{array}$ & & \\
\hline 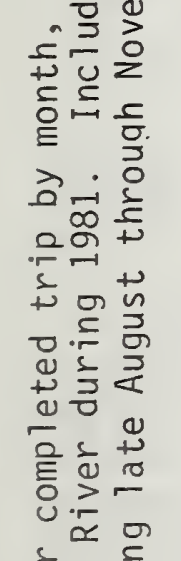 & 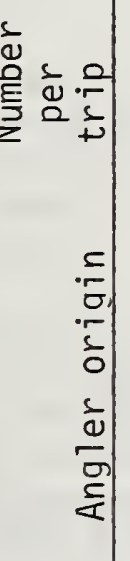 & 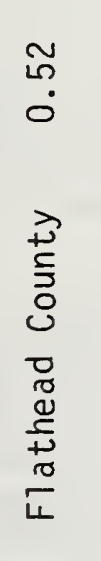 & 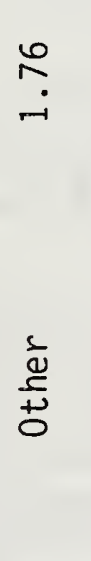 & & \\
\hline 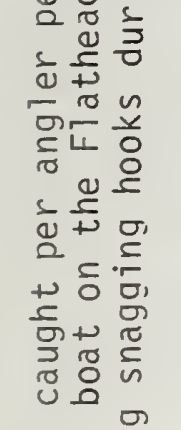 & \begin{tabular}{l|}
0 \\
0 \\
0 \\
+ \\
+ \\
0 \\
$\infty$
\end{tabular} & $\begin{array}{l}0 \\
+\pi \\
\pi \\
\infty \\
\infty\end{array}$ & $\begin{array}{l}\tilde{0} \\
\dot{0} \\
\underset{\leftarrow}{\vec{t}}\end{array}$ & $\stackrel{m}{\stackrel{\sim}{-}}$ & 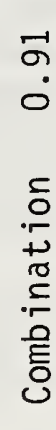 \\
\hline 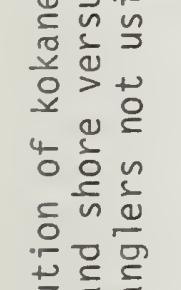 & 恿 & 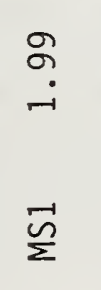 & $\begin{array}{l}\stackrel{0}{0} \\
\dot{0} \\
\tilde{N}\end{array}$ & $\overrightarrow{0}$ & 。 \\
\hline 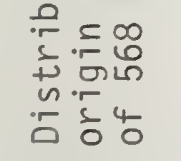 & 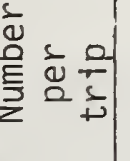 & $\stackrel{d}{\sim}$ & $\begin{array}{l}\stackrel{L}{\infty} \\
\stackrel{\sim}{\sim}\end{array}$ & $\underset{\sim}{\sim} \underset{\sim}{\sim}$ & $\tilde{o}$ \\
\hline $\begin{array}{l}\circ \\
\frac{\sigma}{0} \\
\end{array}$ & 荃 & $\begin{array}{l}\vec{n} \\
\stackrel{\vec{g}}{\vec{z}}\end{array}$ & 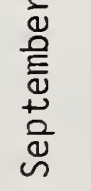 & 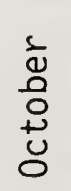 & 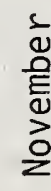 \\
\hline
\end{tabular}


Table 5. Monthly kokanee catch and catch rates (in parentheses) for 169 angler parties not using snagging hooks who were interviewed on Sections MS1-MS4 of the Flathead River during August-November, 1981.

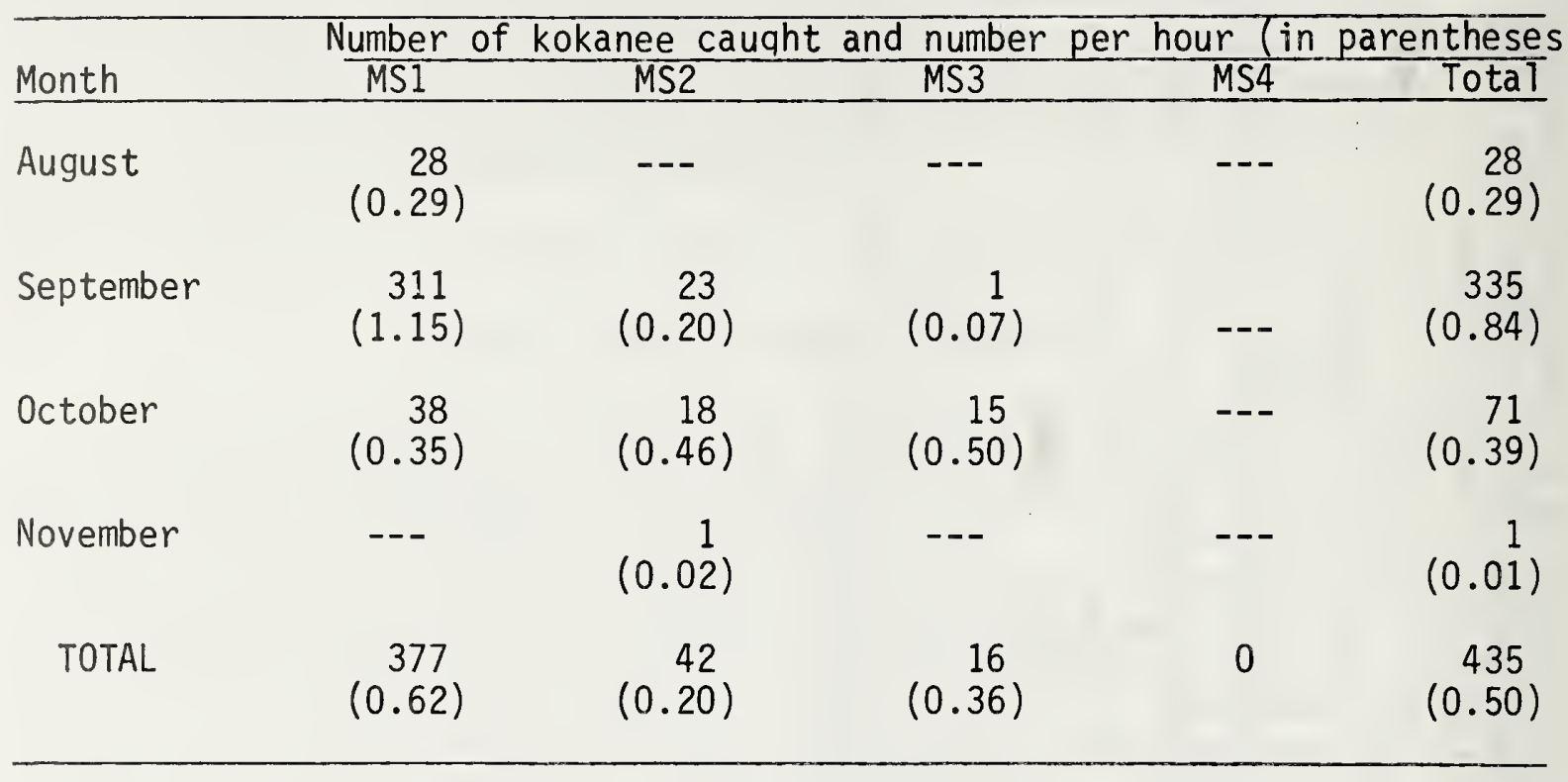


A total of 207 parties of snaggers were interviewed during SeptemberOctober, 1981 on the mainstem Flathead River (Table 6). They accounted for 1,035 hours fished. Snag fishermen made up 63 percent of the total fisherman hours interviewed on the mainstem Flathead during September and 67 percent during October.

This distribution of snag fisherman hours by area by month (Table 6) illustrates the upstream movement of fish. Effort was concentrated in Sections MS1 and MS2 during September, whereas the bulk of the effort shifted to Sections MS3 and MS4 in October. Snag fishermen tended to follow the run of early salmon upstream to their destination of McDonald Creek and the lower Middle Fork of the Flathead River.

There were 354 anglers in the 207 parties interviewed for an average of 1.7 anglers per party, nearly the same as for anglers using conventional methods. About 89 percent of these parties had completed fishing. The average number of hours fished per angler for 316 completed angler trips was 2.9 hours.

The largest difference between conventional angler parties and snag fishermen parties, other than tackle type and catch, occurred in the origin of the anglers. Of 205 snagger parties interviewed, 156 or 76 percent were from Flathead County. Residents from other areas of Montana made up 17 percent of snag fisherman parties interviewed, over three times as high a proportion as for conventional angler parties. Nonresidents and foreigners combined for seven percent of the total parties interviewed. Montanans from outside Flathead County spent a much higher proportion of their fishing effort engaged in kokanee snagging than did local anglers. of the total hours spent by Flathead County anglers interviewed on the mainstem Flathead River during the year, 16 percent was spent snagging for kokanee compared to 29 percent for anglers from other areas.

Kokanee snag fishermen interviewed on the mainstem Flathead River caught 2,090 kokanee for an overall catch rate of 2.0 fish per hour (Table 7). They kept 100 percent of the fish caught.

There was considerable variation in catch rates between the two snagging months and between areas. The overall catch rate in the mainstem Flathead for snag fishermen was 1.7 kokanee per hour during September and 2.7 kokanee per hour during October (Table 7). The most productive section for both months combined was MS3 where snaggers caught 3.4 kokanee per hour. The least productive section was MS2 where snaggers caught 1.4 fish per hour. There was a distinct upstream progression in this fishery.

It appeared that local anglers had much better success snagging kokanee than others. Flathead County residents caught 2.4 kokanee per hour versus 1.4 fish per hour for nonresidents (out of state) and 0.8 fish per hour for other Montanans. It is probable that local anglers were able to follow the progress of the run more closely and knew the location of the more successful snagging areas better than other anglers. Shore anglers had higher success rates than boat anglers, catching 
Table 6. Distribution of snag fisherman interviews and hours by area and month on four sections of the mainstem Flathead River during 1981.

\begin{tabular}{|c|c|c|c|c|c|c|}
\hline \multirow[b]{2}{*}{ Section } & \multicolumn{3}{|c|}{ Number of interviews } & \multicolumn{3}{|c|}{ Number of hours } \\
\hline & September & October & Tota1 & September & October & Total \\
\hline MS1 & 13 & 0 & 13 & 68.2 & 0 & 68.2 \\
\hline MS2 & 88 & 15 & 103 & 455.2 & 50.5 & 505.7 \\
\hline MS 3 & 10 & 28 & 38 & 35.5 & 186.5 & 222.0 \\
\hline MS4 & 29 & 24 & 53 & 114.0 & 125.0 & 239.0 \\
\hline Total & 140 & 67 & 207 & 672.9 & 362.0 & 1034.9 \\
\hline
\end{tabular}

Table 7. Kokanee catch and catch rates (in parentheses) for snag fishermen interviewed on four sections of the mainstem Flathead River during September - October, 1981.

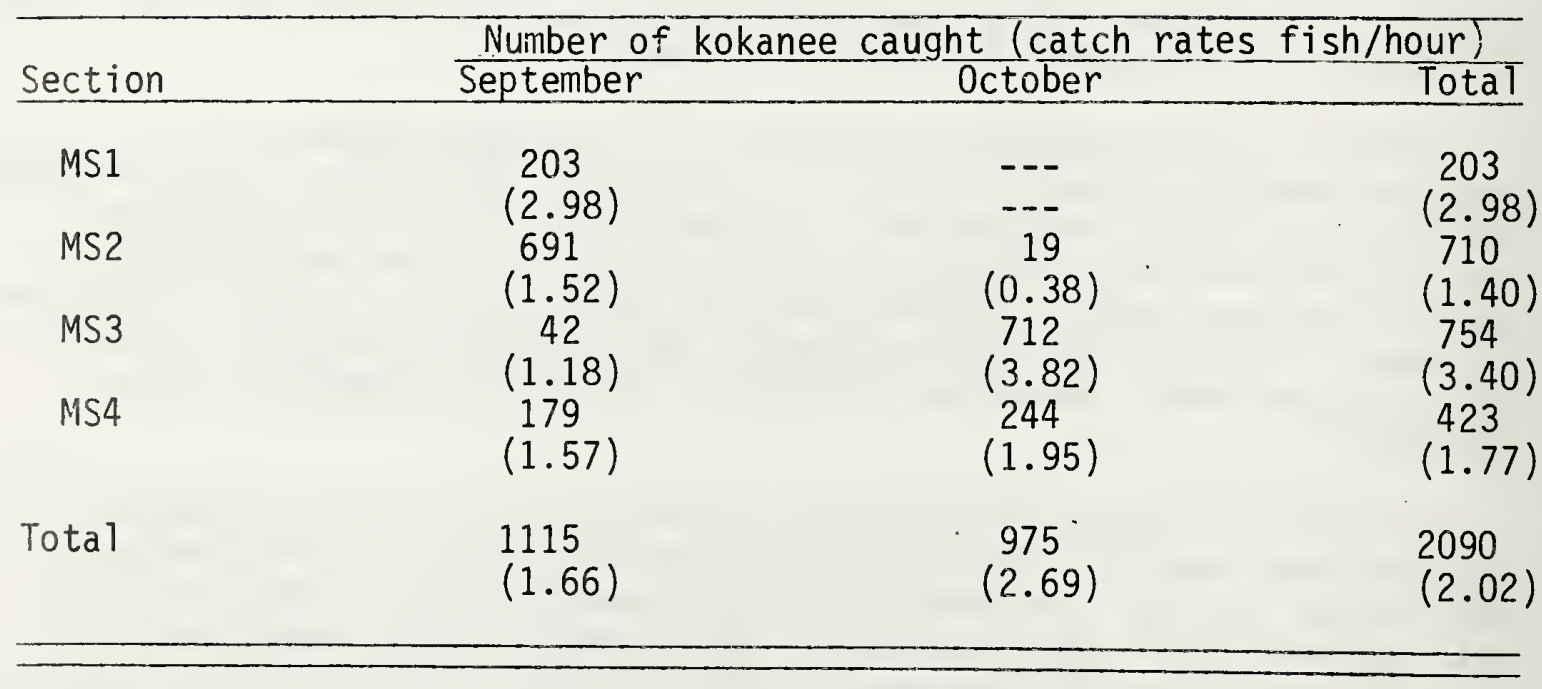


2.1 kokanee per hour compared to 1.8 per hour for boat anglers.

A total of 1,942 kokanee were caught by 185 parties composed of 316 anglers who had completed their trips. This calculated out to 6.1 kokanee per angler per complete trip. Flathead County residents averaged 7.3 kokanee per completed trip versus only 2.8 kokanee per trip for anglers from other origins.

\section{CHARACTERISTICS OF THE KOKANEE FISHERY}

\section{Snag Fishery Middle Fork}

A total of 237 parties were interviewed on the Middle Fork of the Flathead River during September-0ctober of 1981. A11 237 of those interviews were conducted on Section MF1, the Middle Fork below the mouth of Harrison Creek. All interviews were exclusively with snag fishermen. observation indicated that very few fishermen were involved in any other type of fishery during this time period, hence the entire fishery could be characterized by this sample.

About one-third of the interviews were conducted during September and two-thirds during October (Table 8). Nearly 90 percent of the parties interviewed had completed their fishing trips for the day. Seventythree of the interviews (31\%) were conducted during the weekends and the remainder during the week.

The 237 parties interviewed accounted for a total of 2,565 hours fished (Table 8). Shore fishermen accounted for 88 percent of these hours with boat fishermen contributing the other 12 percent.

Anglers from out of Flathead County had larger parties and fished longer per trip. As a result, Montana anglers from outside Flathead County accounted for about 61 percent of the total hours fished on the Middle Fork while County resident comprised only 19 percent of the hours fished (Table 9).

The mean party size for snag fishermen on the Middle Fork was 2.2 anglers per party. Mean party size was only 1.9 for Flathead County anglers versus 2.4 for other Montanans. Nonresidents averaged 2.6 anglers per party and Canadians averaged 1.7 anglers per party. The mean length of completed trips for Flathead County anglers was 3.7 hours. This compares to 5.2 hours per completed trip for other Montanans and nonresidents. The overall average length of completed trip per angler was 4.7 hours for 462 anglers.

The average distance from home for all angler parties was 211 miles. Flathead County anglers drove an average of 41 miles to fish the Middle Fork while other Montanans averaged 244 miles from home. Canadians were $231 \mathrm{miles}$ from home, with the largest average distance traveled being 608 miles by nonresidents. 
Table 8. Numbers of parties interviewed and hours fished by month on the Middle Fork of the Flathead River during September October, 1981.

\begin{tabular}{lccccc}
\hline Month & $\begin{array}{c}\text { Number of } \\
\text { party } \\
\text { interviews }\end{array}$ & $\begin{array}{c}\text { Number of } \\
\text { complete trips }\end{array}$ & $\begin{array}{c}\text { Complete } \\
\text { trip } \\
\text { hours }\end{array}$ & $\begin{array}{c}\text { Incomplete } \\
\text { trip } \\
\text { hours }\end{array}$ & $\begin{array}{r}\text { Total } \\
\text { hours }\end{array}$ \\
\hline September & 85 & 76 & 769.9 & 109.3 & 879.2 \\
October & 152 & 132 & 1402.9 & 283.5 & 1686.4 \\
Total & 237 & 208 & 2172.8 & 392.8 & 2565.6 \\
\hline
\end{tabular}

Table 9. Distribution of angler origins for snag fishermen interviewed on the Middle Fork of the Flathead River during September October, 1981.

\begin{tabular}{lcccrr}
\hline & $\begin{array}{c}\text { Flathead } \\
\text { County }\end{array}$ & $\begin{array}{c}\text { 0ther } \\
\text { Montanan }\end{array}$ & $\begin{array}{c}\text { US } \\
\text { nonresident }\end{array}$ & Canadian & Total \\
\hline $\begin{array}{l}\text { Number of parties } \\
\begin{array}{l}\text { Number of hours } \\
\text { fished }\end{array}\end{array}$ & 69 & 125 & 28 & 12 & 234 \\
$\begin{array}{l}\text { \% of parties } \\
\text { of hours fished }\end{array}$ & 30 & 1,552 & 392 & 117 & 2,539 \\
& 19 & 61 & 15 & 5 & -- \\
\hline
\end{tabular}


A total of 4,934 kokanee were caught by snag fishermen interviewed on the Middle Fork during September - October, 1981. Catch rates for these kokanee snaggers were 1.9 fish per hour overall with anglers catching 2.0 fish per hour during September and 1.9 kokanee per hour during 0ctober. Catch rates for the two months were remarkably constant. Virtually all of the kokanee caught by anglers were kept. Snag fishermen also illegally caught and kept twelve whitefish.

The average angler with completed trip caught 9.5 kokanee per day. Flathead County anglers kept 12.0 kokanee per trip, catching them at the rate of 3.2 kokanee per hour. Other Montana residents caught 1.7 kokanee per hour and kept 9.0 per trip. Nonresidents caught 1.4 kokanee per hour, the lowest success rate of any group, and kept 7.2 fish per completed trip.

The catch rate for boat anglers was 60 percent higher than for shore anglers. Shore anglers caught 4,075 kokanee in 2,268 hours for an average catch rate of 1.8 kokanee/hour. Boat anglers caught 859 kokanee in 298 hours for a catch rate of 2.9 kokanee/hour. A total of 23 percent of local angler parties used boats, compared to only four percent of al1 non-local angler parties.

The greater success rate for local kokanee snaggers in part was attributable to their use of boats. Locating and accessing large schools of kokanee was probably the primary advantage of using boats.

\section{FISHING PRESSURE}

\section{Mainstem Flathead River}

Fishing pressure could not be estimated solely for kokanee fishermen because kokanee anglers could not be distinguished from other fishermen during our counts. The following section includes pressure estimates for the entire season for all anglers, although kokanee fishermen dominated the September and October fishery.

During the entire 1981 fishing season, anglers on the mainstem Flathead River fished an estimated 115,727 hours (Table 10). Of this total pressure, 13 percent occurred in Section MS1, 47 percent in Section MS2, 20 percent in Section MS3, and 20 percent in Section MS4. On a pressure/km basis, Section MS2 was the most heavily fished, with 2,838 fisherman hours $/ \mathrm{km}$. This was followed in order by Sections MS 3, MS4 and MS1 with 2,192, 1,001, and 423 fisherman hours/km, respectively. Sections MS2 and MS3, which were the most heavily fished, were also located adjacent to the major local population centers.

\section{Another frequently used statistic for examining fishing pressure} is the evaluation of man-days fishing. This was calculated by dividing the estimated total pressure in hours by the average length of completed trip for a particular section or time period. On the mainstem Flathead River the average length of a completed trip was 3.2 hours. Thus, the total estimated 115,727 fisherman hours represented 35,940 man-days of fishing pressure. 
Table 10. Total estimated fishing pressure in hours, by month, with 95\% confidence intervais (in parentheses) for Sections MS1MS4 of the Flathead River during 1981.

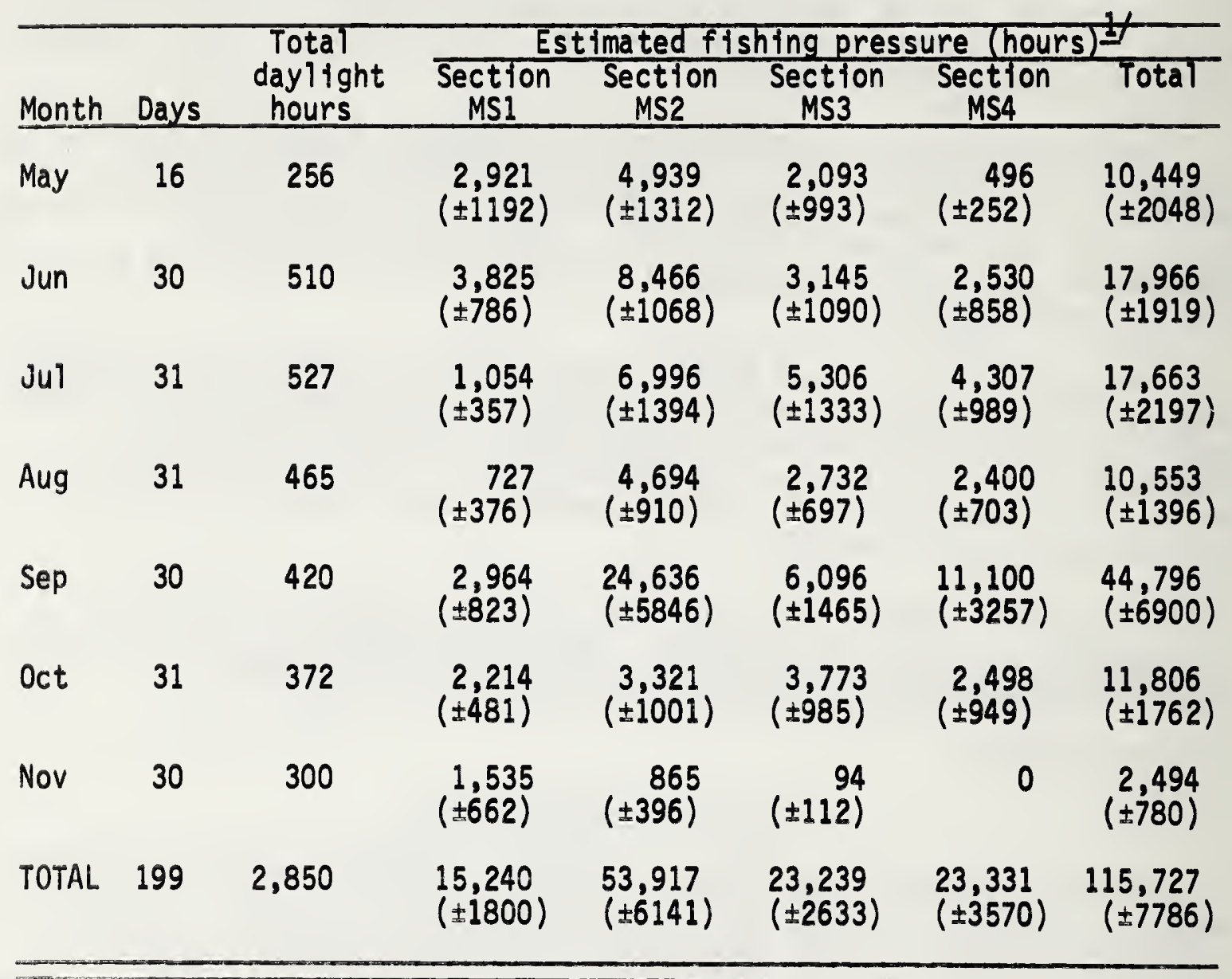

1/ $95 \%$ confidence intervals in parentheses. 
The number of hours interviewed was 4.4 percent of the total estimated boat pressure and 5.1 percent of the estimated shore pressure during the season. Percent of estimated total fisherman hours that were interviewed was $2.4 \%$ in September and $4.6 \%$ in 0ctober in the mainstem.

An estimated 39 percent of the total fishing pressure on the Flathead River occurred during the month of September, coinciding with the onset of the fal1 kokanee run in the mainstem. October, which included the latter part of the kokanee run, accounted for 10 percent of the total pressure. This would probably have been higher, but the kokanee snag season ended by an emergency closure on October 23, 1981 in the mainstem below the mouth of the South Fork. November accounted for only two percent of the total fishing pressure.

Of the total fishing pressure on the mainstem Flathead nearly 73 percent was by shore anglers (Table 11). The largest monthly proportion of the effort by shore fishermen on the mainstem, 35 percent, occurred in September with the beginning of the kokanee fishery. October contributed an additional 11 percent to the total shore fisherman pressure on the ma instem (Table 11).

On a monthly basis, the majority of boat use on the mainstem, 49 percent, occurred during September but decreased to seven percent of the total boat use in October after the kokanee had migrated upstream (Table 12).

Total boat fishing pressure was largest in Section MS2 with 829 fisherman hours per km, followed by Sections MS3, MS1 and MS4 with 482, 186 and 170 hours per $\mathrm{km}$, respectively.

Total shore fishing pressure was 238 hours/km on Section MS1, 2009 hours/km on Section MS2, 1,711 hours/km on MS3, and 831 hours/km on Section MS4. Part of the reason for low shore pressure on Section MS1 may be 1 imited access.

\section{Middle Fork}

This portion of the census was to estimate pressure for the fal1 kokanee snagging fishery only. During the period covered, virtually no fishing pressure for other species (using conventional tackle) existed. No attempt was made to obtain pressure estimates on the Middle Fork further upstream in the Bob Marsha11 Wi1derness or on Sections MF1 and MF2 during the summer period.

The total estimated fishing pressure for the Middle Fork kokanee fishery was 37,870 fisherman hours (Table 13). Of the total, 97 percent occurred in section MF1. The total fishing pressure per $\mathrm{km}$ was 1,690 fisherman hours per km on Section MF1 and 29 hours per km on Section MF2. The number of hours interviewed was 6.8 percent of the total estimated pressure, with 4.1 percent in September and 10.3 percent in 0ctober. 
Table 11. Total estimated shore fishing pressure in hours, by month, with $95 \%$ confidence intervals (in parentheses) for Sections MS1-MS4 of the Flathead River during 1981.

\begin{tabular}{|c|c|c|c|c|c|c|c|}
\hline \multirow[b]{2}{*}{ Month } & \multirow[b]{2}{*}{ Days } & \multirow{2}{*}{$\begin{array}{l}\text { Total } \\
\text { daylight } \\
\text { hours }\end{array}$} & \multicolumn{5}{|c|}{ Estimated fishing pressure (hours) 1 f } \\
\hline & & & $\begin{array}{c}\text { Section } \\
\text { MS1 }\end{array}$ & $\begin{array}{c}\text { Section } \\
\text { MS2 }\end{array}$ & $\begin{array}{c}\text { Section } \\
\text { MS3 }\end{array}$ & $\begin{array}{l}\text { Section } \\
\text { MS4 }\end{array}$ & Total \\
\hline May & 16 & 256 & $\begin{array}{c}2,003 \\
( \pm 1106)\end{array}$ & $\begin{array}{c}4,518 \\
( \pm 1253)\end{array}$ & $\begin{array}{r}2,048 \\
( \pm 989)\end{array}$ & $\begin{array}{r}448 \\
( \pm 231)\end{array}$ & $\begin{array}{c}9,017 \\
( \pm 1955)\end{array}$ \\
\hline Jun & 30 & 510 & $\begin{array}{r}2,720 \\
( \pm 685)\end{array}$ & $\begin{array}{c}8,075 \\
( \pm 1024)\end{array}$ & $\begin{array}{c}3,043 \\
( \pm 1081)\end{array}$ & $\begin{array}{r}2,413 \\
( \pm 839)\end{array}$ & $\begin{array}{l}16,251 \\
( \pm 1841)\end{array}$ \\
\hline Jul & 31 & 527 & $\begin{array}{r}727 \\
( \pm 247)\end{array}$ & $\begin{array}{c}4,997 \\
( \pm 1055)\end{array}$ & $\begin{array}{r}3,471 \\
( \pm 995)\end{array}$ & $\begin{array}{r}3,507 \\
( \pm 801)\end{array}$ & $\begin{array}{l}12,702 \\
( \pm 1674)\end{array}$ \\
\hline Aug & 31 & 465 & $\begin{array}{r}233 \\
( \pm 141)\end{array}$ & $\begin{array}{r}2,369 \\
( \pm 644)\end{array}$ & $\begin{array}{r}1,395 \\
( \pm 424)\end{array}$ & $\begin{array}{r}1,665 \\
( \pm 600)\end{array}$ & $\begin{array}{r}5,662 \\
( \pm 987)\end{array}$ \\
\hline Sep & 30 & 420 & $\begin{array}{r}384 \\
( \pm 209)\end{array}$ & $\begin{array}{l}15,396 \\
( \pm 4496)\end{array}$ & $\begin{array}{c}4,524 \\
( \pm 1192)\end{array}$ & $\begin{array}{c}9,024 \\
( \pm 3184)\end{array}$ & $\begin{array}{l}29,328 \\
( \pm 5641)\end{array}$ \\
\hline oct & 31 & 372 & $\begin{array}{r}1,346 \\
( \pm 396)\end{array}$ & $\begin{array}{r}2,391 \\
( \pm 930)\end{array}$ & $\begin{array}{r}3,561 \\
( \pm 953)\end{array}$ & $\begin{array}{r}2,303 \\
( \pm 943)\end{array}$ & $\begin{array}{c}9,601 \\
( \pm 1679)\end{array}$ \\
\hline Nov & 30 & 300 & $\begin{array}{r}1,147 \\
( \pm 580)\end{array}$ & $\begin{array}{r}424 \\
( \pm 320)\end{array}$ & $\begin{array}{r}94 \\
( \pm 112)\end{array}$ & 0 & $\begin{array}{r}1,665 \\
( \pm 672)\end{array}$ \\
\hline TOTAL & 199 & 2,850 & $\begin{array}{c}8,560 \\
( \pm 1420)\end{array}$ & $\begin{array}{l}38,170 \\
( \pm 4825)\end{array}$ & $\begin{array}{l}18,136 \\
( \pm 2274)\end{array}$ & $\begin{array}{l}19,360 \\
( \pm 3438)\end{array}$ & $\begin{array}{l}84,226 \\
( \pm 6503)\end{array}$ \\
\hline
\end{tabular}

1/ $95 \%$ confidence intervals in parentheses. 
Table 12. Total estimated boat fishing pressure in hours, by month, with $95 \%$ confidence intervals (in parentheses) for Sections MS1-MS4 of the Flathead River during 1981.

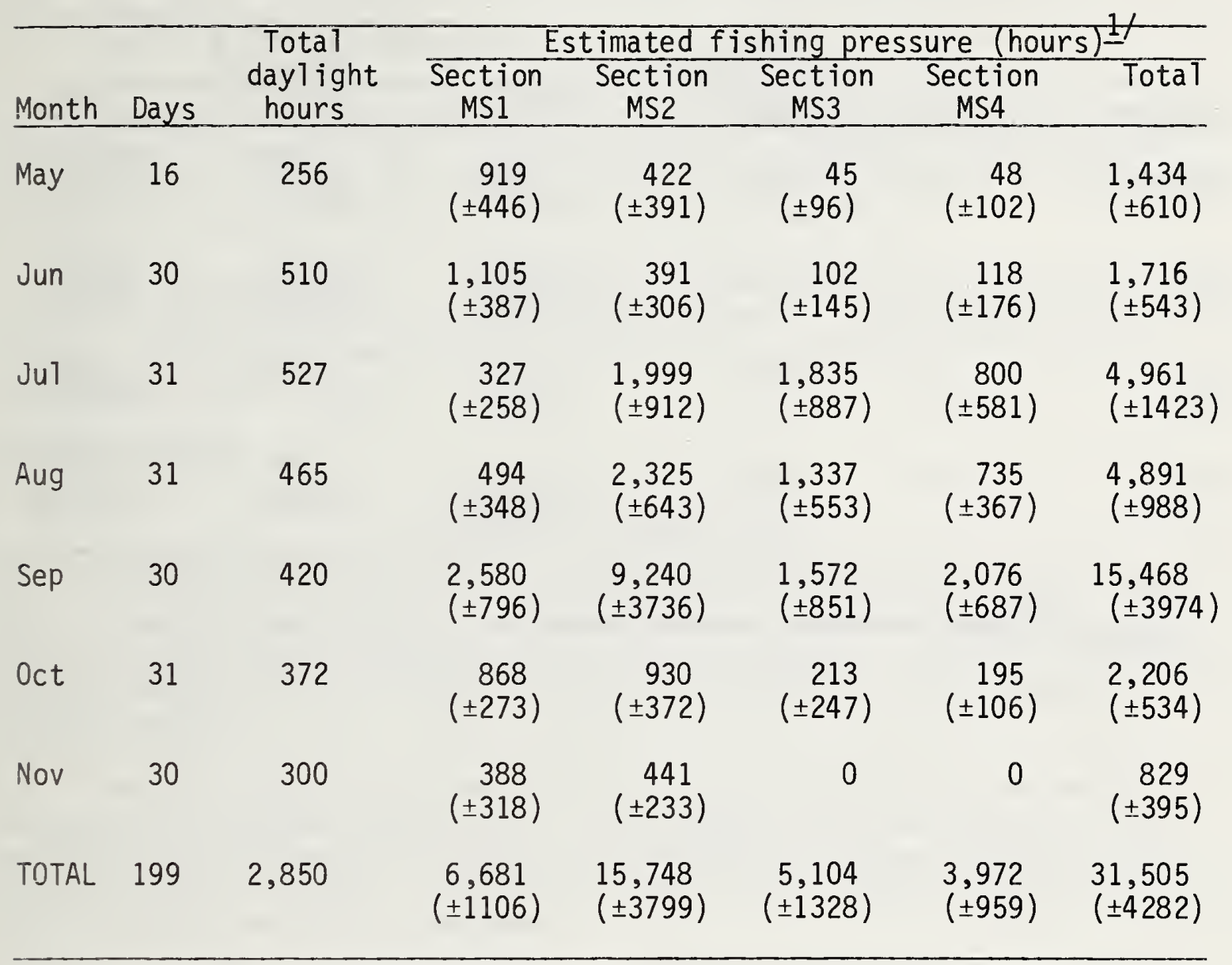

$1 / 95 \%$ confidence intervals in parentheses. 
Table 13. Total estimated fisherman pressure in hours exerted by kokanee snagger from shore and in boats on the lower Middle Fork of Flathead River during September-November, 1981.

\begin{tabular}{|c|c|c|c|c|c|}
\hline \multirow[b]{2}{*}{ Month } & \multirow[b]{2}{*}{ Days } & \multirow{2}{*}{$\begin{array}{c}\text { Total } \\
\text { dayl ight } \\
\text { hours }\end{array}$} & \multicolumn{3}{|c|}{$\begin{array}{l}\text { Estimated fishing pressure } \\
\text { (hours) } 1 \text {. }\end{array}$} \\
\hline & & & Shore & Boat & Total \\
\hline Sep $12-30$ & 19 & 247 & $\begin{array}{l}19,303 \\
( \pm 3872)\end{array}$ & $\begin{array}{l}2,122 \\
( \pm 573)\end{array}$ & $\begin{array}{l}21,425 \\
( \pm 3915)\end{array}$ \\
\hline Oct & 31 & 372 & $\begin{array}{l}14,145 \\
( \pm 3095)\end{array}$ & $\begin{array}{l}1,807 \\
( \pm 601)\end{array}$ & $\begin{array}{l}15,952 \\
( \pm 3153)\end{array}$ \\
\hline Nov & 30 & 300 & $\begin{array}{r}493 \\
( \pm 819)\end{array}$ & 0 & $\begin{array}{r}493 \\
( \pm 819)\end{array}$ \\
\hline TOTAL & 80 & 919 & $\begin{array}{l}33,941 \\
( \pm 5046)\end{array}$ & $\begin{array}{l}3,929 \\
( \pm 812)\end{array}$ & $\begin{array}{l}37,870 \\
( \pm 5115)\end{array}$ \\
\hline
\end{tabular}

1/ $95 \%$ confidence intervals in parentheses. 
Nearly 57 percent of the total pressure for the 80 day survey period occurred during the 19 days of September. October accounted for 42 percent of the total pressure and the entire month of November produced only one percent. This was essentially a seven week fishery, from September 12 to October 31 .

Of the fishing pressure on the Middle Fork, nearly 90 percent was by shore anglers. Boat anglers were evenly distributed during September and October in Section MF1, but no boat use was detected in Section MF2 nor in Section MF1 during November. Boat fishermen produced 181 fisherman hours $/ \mathrm{km}$ of pressure during this period on Section MF1.

The estimated total of 37,870 hours fished divided by the average length of completed trips on the Middle Fork of 4.7 hours yields an estimated total of 8,040 fisherman-days expended on the lower Middle Fork during the kokanee snag fishery.

KOKANEE HARVEST

Ma instem Flathead River

Total estimated harvest on the mainstem Flathead River during 1981 for all anglers was 89,273 game fish (Fredenberg and Graham 1982). Of this estimated total, about 86 percent were kokanee, 10 percent cutthroat trout, two percent bull trout, two percent whitefish, and 0.5 percent rainbow trout.

Almost the entire kokanee harvest occurred during only two months, September and October (Table 14). A few kokanee were harvested at the end of August by boat fishermen in Section MS1, but they contributed only 0.2 percent of the total. Over 75 percent of the kokanee harvest on the mainstem occurred during September.

Of the four mainstem areas, Section MS2 contributed 41 percent of the total kokanee harvest (Table 14). Section MS4 produced 28 percent of the harvest, Section MS3 23 percent, and Section MS1 eight percent. A7most 62 percent of the harvest during September occurred in Sections MS1 and MS2. During 0ctober this trend had reversed; over 90 percent of the kokanee harvest occurred in Sections MS3 and MS4. Distribution of harvest reflected the upstream movement of the spawning run. The snagging season was closed October 23 in all but the upper half of Section MS4.

About 27 percent of the total kokanee harvest was by boat anglers (Table 15). There was heavier emphas is by boat fishermen during September than october. This was no doubt related to the tendency towards greater boat use in Sections MS1 and MS2, where most of the harvest occurred during September. Over 69 percent of the kokanee harvest in Section MS1 was by boat anglers. This decreased in upstream order to 39 percent in Section MS2 and less than one percent in Section MS3, but then increased again to 18 percent in Section MS4. Almost 58 percent of the entire total estimated boat angler harvest of kokanee occurred during September on Section MS2 (Table 15). Shore anglers contributed about 73 percent of the total kokanee harvest (Table 16) with Section MS2 during September producing the peak for any one area and month. 
Table 14. Total estimated monthly kokanee harvest by all anglers on the four sections of the mainstem Flathead River during 1981. 95\% confidence interval in parentheses for grand total.

\begin{tabular}{|c|c|c|c|c|c|}
\hline \multirow[b]{2}{*}{ Month } & \multicolumn{5}{|c|}{ Estimated numbers of kokanee harvested } \\
\hline & MS1 & MS2 & MS3 & MS4 & Total \\
\hline August & 138 & 0 & 0 & 0 & 138 \\
\hline September & 5,377 & 30,467 & 5,464 & 16,822 & 58,130 \\
\hline October & 524 & 1,323 & 11,940 & 4,775 & 18,562 \\
\hline November & 0 & 0 & 0 & 0 & 0 \\
\hline TOTAL & 6,039 & 31,790 & 17,404 & 21,597 & $\begin{array}{c}76,830 \\
( \pm 18,836)\end{array}$ \\
\hline
\end{tabular}

Table 15. Total estimated monthly kokanee harvest by boat anglers only on the four sections of the mainstem Flathead River during 1981. 95\% confidence interval in parentheses for grand total.

\begin{tabular}{lrrrrr}
\hline Month & \multicolumn{5}{c}{ Estimated numbers of kokanee harvested } \\
\cline { 2 - 6 } & MS1 & MS2 & MS3 & MS4 & Total \\
August & 138 & 0 & 0 & 0 & 138 \\
September & 3,534 & 11,982 & 112 & 3,864 & 19,492 \\
October & 524 & 441 & 0 & 130 & 1,095 \\
November & 0 & 0 & 0 & 0 & 0 \\
TOTAL & 4,196 & 12,423 & 112 & 3,994 & 20,725 \\
& & & & & $( \pm 8,771)$ \\
\hline
\end{tabular}


Table 16. Total estimated monthly kokanee harvest by shore anglers only on the four sections of the mainstem Flathead River during

1981. 95\% confidence interval in parentheses for grand total.

\begin{tabular}{lrrrrr}
\hline Month & \multicolumn{5}{c}{ Estimated numbers of kokanee harvested } \\
\cline { 2 - 6 } & MS1 & MS2 & MS3 & MS4 & Tota1 \\
September & 1,843 & 18,485 & 5,352 & 12,958 & 38,638 \\
October & 0 & 882 & 11,940 & 4,645 & 17,467 \\
November & 0 & 0 & 0 & 0 & 0 \\
TOTAL & 1,843 & 19,367 & 17,292 & 17,603 & 56,105 \\
& & & & & $( \pm 16,669)$ \\
\hline
\end{tabular}


The total estimated kokanee harvest on the Middle Fork of the Flathead River during the fall of 1981 was 75,117 spawners (Table 17). The period covered by the census included the entire time span that kokanee were known to be in the Middle Fork. All fish were taken by snagging.

Of the total harvest, almost 59 percent occurred during the last 19 days of September. October accounted for 40 percent of the harvest and November produced the remaining one percent.

The entire harvest of kokanee on the Middle Fork occurred between the mouth of the river and Deerlick Creek with the majority occurring in the vicinity of McDonald Creek.

Of the total estimated harvest about 21 percent was attributed to anglers using boats (Table 17). They experienced better than average success as only about 10 percent of the total pressure was by boat fishermen. Most of the boat fisherman harvest (75\%) occurred during September.

\section{South Fork and Swan River}

Four fisherman parties fishing a total of 15 hours were interviewed during October on the South Fork of the Flathead River. These anglers caught 155 kokanee, all by snagging. The purpose of presenting this data, even though it was not a complete census, was to document that some kokanee snagging did occur on the South Fork downstream from Hungry Horse Dam during 1981 despite the erratic water levels caused by discharge fluctuations.

A substantial kokanee snag fishery also occurred on the Swan River below Bigfork Dam. During the month of November, 198123 angler parties were interviewed. They were responsible for 127 fisherman hours of pressure. These anglers caught 477 kokanee, all by snagging. The snag fishery on the Swan River received heavy use during the spawning run. To insure adequate reproduction occurred in this area and because of the vulnerability of these kokanee, this fishery was closed to snagging beginning in 1982 for a distance of 300 feet directly downstream from the dam.

\section{SIZE DISTRIBUTION OF KOKANEE HARVESTED ON THE MAINSTEM AND MIDDLE FORK}

The average length of 489 fish taken by anglers from the mainstem Flathead River (Sections MS1-MS4) and the lower Middle Fork (Section MF1) during September and 0ctober was $361 \mathrm{~mm}$. The range was 321-420 mm. Most of these fish were taken by snagging.

The frequency distribution of these 489 kokanee (Figure 3 ) showed a sample with a strong mode at $350-370 \mathrm{~mm}$. This uniformity of size was consistent with what would be expected from a spawning run dominated by fish in one age class. The mean length of $371 \mathrm{~mm}$ in 1981 was the largest average size of kokanee spawners since record-keeping began in 1951. 
Table 17. Total estimated kokanee harvest by shore and boat snag fishermen on the lower Middle Fork of the Flathead River during September November, 1981. 95\% confidence interval in parentheses for totals.

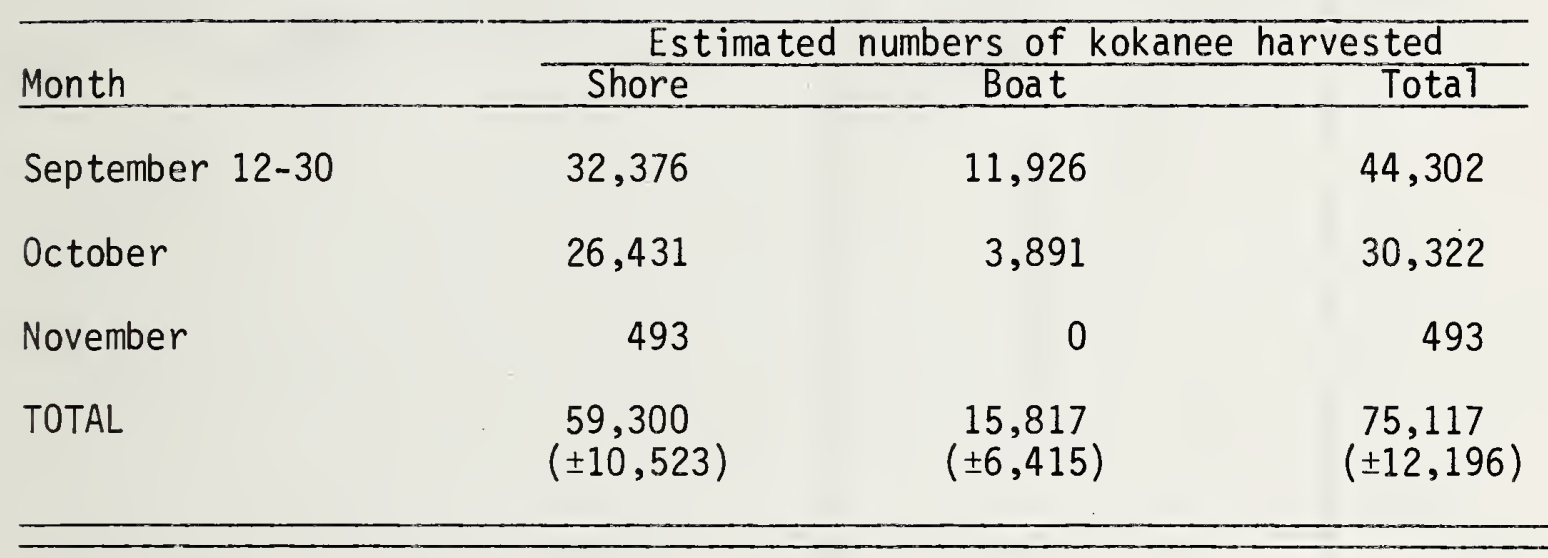




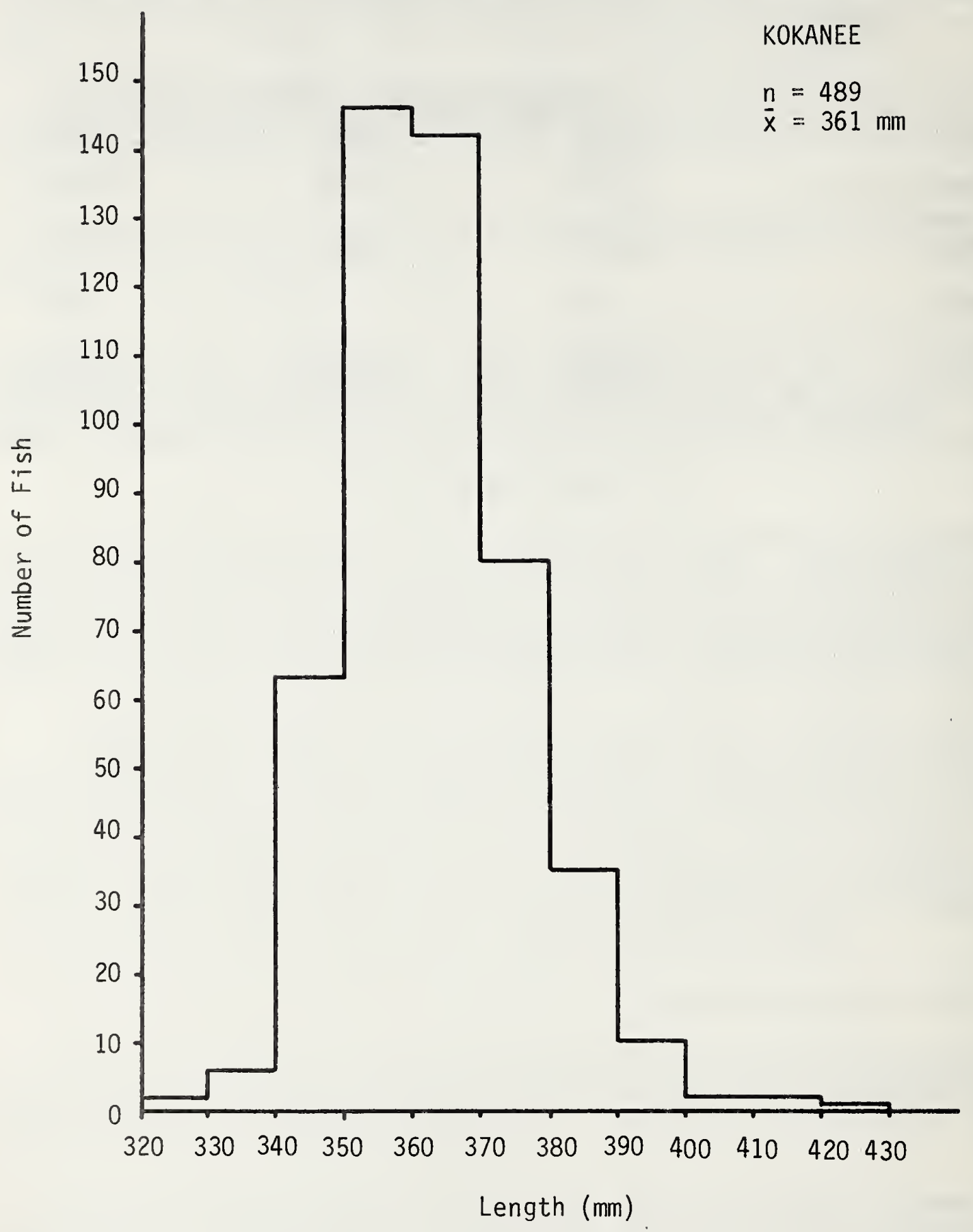

Figure 3. Length frequency distribution of 489 kokanee harvested by fishermen from the Flathead River (Sections MS1-MS4) and lower Middle Fork (Section MF1) during 1981. 
Ninety-five percent of the kokanee in the sample were between 340 and $390 \mathrm{~mm}$ (Figure 3 ). The average length of adult males (368 mm) exceeded that of adult females $(355 \mathrm{~mm}$ ) by $13 \mathrm{~mm}$, due primarily to the elongated development of the lower jaw common in males of Pacific Salmon species. 
During the 1981 kokanee season on the mainstem Flathead River and the lower Middle Fork (September-November) anglers expended an estima ted total of 97,000 fisherman hours which equated to over 26,000 angler days. During this period an estimated total of 152,000 kokanee were harvested with approximately equal harvest from the Middle Fork and mainstem Flathead rivers. Over 90 percent of this harvest was by snag fishermen.

Distribution of pressure and harvest between the two rivers varied through the season. On the mainstem Flathead over three-fourths of the pressure and kokanee harvest occurred during the month of September. By October, the pressure and harvest on the mainstem had moved upstream to Sections MS3 and MS4. The closure of this fishery in 271 but the upper end of Section MS4, on October 23, effectively ended kokanee harvest for the year on the mainstem. Flathead.

On the Middle Fork of the Flathead, about 57 percent of the pressure and 59 percent of the kokanee harvest occurred during only a 19-day period at the end of September. Nearly all the remaining pressure and harvest occurred during October. Despite the fact that the season remained open there was very little fishing activity during November for kokanee. The majority of these fish had migrated into McDonald Creek, the principle spawning area and a tributary to the Middle Fork, which was closed to fishing.

It was evident that as the run of kokanee progressed upstream through the mainstem and into the Middle Fork (Fraley and Graham 1982) much of the angler activity also shifted in emphasis. Catch rates for snag fishermen interviewed on the two rivers were both approximately two fish per hour.

\footnotetext{
A comparison of the 1981 kokanee fishery to the census in 1975 (Hanzel $1977)^{1}$ yielded some very alarming comparisons. During 1975 the total estimated kokanee harvest in the Flathead River system was 150,000 fish, about the same as that estimated to have occurred during 1981. However, there was a significant difference in the distribution of the harvest.
}

During 1975, virtually the entire kokanee harvest of 150,000 fish came from the mainstem Flathead River (Hanzel 1977). There was very little activity associated with any kokanee fishery on the Middle Fork of the Flathead River. Thus, the harvest in the mainstem of 77,000 kokanee in 1981 represented a decline of 49 percent.

1 Values from 1975 census were revised to correct for an error in the estimated pressure. 
There was also a shift in the timing and location of harvest and pressure from 1975 to 1981 on the mainstem Flathead. During 1975, about 88 percent of the mainstem kokanee harvest occurred during the month of October (Hanzel 1977) compared to 24 percent in 1981. Less than 12 percent of the ma instem harvest occurred during September in 1975, compared to 76 percent in 1981. During 1975, an estimated 69,276 fisherman hours were expended during October on the mainstem Flathead River compared to less than 12,000 in 1981 .

A very limited amount of fishing pressure for kokanee occurred on the lower 30 miles of the Middle Fork in the fall of 1975, compared to nearly 38,000 hours during the fall of 1981 . The apparent shift in the kokanee fishery in 1981 to the lower Middle Fork reflected a change in emphasis by fishermen in response to a declining kokanee run in the mainstem (Fraley and Graham 1982). The early (September) run of fish were destined to McDonald Creek spawning areas. A later (October) run of fish were destined for mainstem spawning areas.

Conclusions from a three-year study on the effects of Hungry Horse Dam on the Flathead River kokanee fishery (Fraley and Graham 1982) were that the water level fluctuations from the dam caused excessive egg mortality in the mainstem Flathead River below the South Fork due to dewatering of incubating eggs and subsequent freezing and/or dessication. As a result the historically strong run of fish that spawned in the mainstem Flathead River, as evidenced by the 1975 fishery that occurred there during the month of October had been reduced to only 11 percent of the 1975 level (Fraley and Graham 1982). The earlier portion of the run which spawned primarily in McDonald Creek had not been similarly affected by discharge from Hungry Horse Dam. As a result, its relative importance significantly increased with 50 percent of the total river kokanee harvest coming from the Middle Fork during 1981. Exploitation of the earlier Middle Fork run increased from 1975 probably as a result of a shift in fisherman use following the decline in the late run. The early run was not exploited previously probably because it was more unpredictable in timing and rate of migration compared to the later run fish which spawned in the mainstem closer to the population center of Kalispell.

In response to the declining kokanee run in the mainstem river in 1981 for the third consecutive year, the Fish and Game Commission imposed an emergency closure for snagging of kokanee on 23 october. The regulations were changed for 1982 to protect the late run by closing the snag fishery two and one-half months earlier, on 15 October, and also to reduce the increasing pressure on the early run by delaying the opening to 15 September.

The result of the kokanee spawning study (Fraley and Graham 1982) has been the proposal of flow recommendations that would maintain the river at Columbia Falls at a minimum flow of $3,500 \mathrm{cfs}$ during the period from October 15-April 15 to protect the eggs from dewatering. In addition, the flow would not exceed 4,500 cfs during the October 15-December 15 spawning period in order to prevent fish from spawning in areas that will be subsequently dewatered. In meeting these flows, the mainstem kokanee run could be built back up to levels that would provide a balanced number 
of medium size kokanee spawners rather than small numbers of large spawners such as occurred in 1981. This would have the benefit of improving the mainstem kokanee fishery to the base level observed in 1975. Recovery of the late run could result in fisherman use much larger than observed in either 1975 or 1981 if interest in fishing the early run were to continue. Increased numbers of spawners would also result in lengthening the snag season providing increased angler opportunity. 
Fraley, J., D. Read, and P. Graham. 1981. Flathead River Basin fishery study. Mont. Dept. of Fish, Wildlife and Parks. Kalispell, MT 193p.

Fraley, J.J., and P.J. Graham. 1982. The impact of Hungry Horse Dam on the fishery of the Flathead River - Final Report. Mont. Dept. of Fish, Wildlife and Parks. Kalispell, Montana. 125p.

Fredenberg, W., P. Graham. 1982. Flathead River fisherman census. Mont. Dept. of Fish, Wildlife and Parks. Kalispell, MT.

Graham, P.J., D. Read, S. Leathe, J. Miller and K. Pratt. 1980. Flathead River Basin fishery study. Mont. Dept. of Fish, Wildlife and Parks. Kalispe11, MT. 166 p.

Graham, P.J. and W. Fredenberg. 1982. Flathead Lake fisherman census . Mont. Dept. of Fish, Wildlife and Parks. Kalispell, MT

Hanzel, D.A. 1977. Angler pressure and game fish harvest estimates for 1975 in the Flathead River system above Flathead Lake. Fisheries Investigations Report, Hont. Dept. of Fish and Game, Helena. Project No. P-1-23.

Picliullin, S.L. and P.J. Graham. 1981. The impact of Hungry Horse Dam on the kokanee fishery of the Flathead River. Mont. Dept. of Fish, Wildlife and Parks, Kalispe11, MT. 98 p.

Neuhold, J. M and K. H. Lu. 1957. Creel census method. Utah State Department of Fish and Game, Publication No. 8, Salt Lake City, Utah. 36 p.

Perry, S. and P. Graham. 19E1. The impacts of Hungry Horse Dam on the Aquatic invertebrates of the Flathead River. Mont. Dept. of Fish, Wildlife and Parks. Kalispell, MT. $110 \mathrm{p}$.

Sutherland, R. 1982. Recreation and preservation valuation estimates for the Flathead River and Lake System, in conjunction with Mont. Dept. of Fish, Wildlife and Parks, Flathead River Basin Environmental Impact Study, E.P.A. 


